$8-2010$

\title{
A Historical Analysis of Special Education Services in Conservative Christian Schools Since 1950
}

Kristi-Lynn Craig

Cedarville University

Follow this and additional works at: http://digitalcommons.cedarville.edu/education_theses

Part of the Special Education and Teaching Commons

\section{Recommended Citation}

Craig, Kristi-Lynn, "A Historical Analysis of Special Education Services in Conservative Christian Schools Since 1950" (2010). Master of Education Research Theses. 28.

http://digitalcommons.cedarville.edu/education_theses/28 
A Historical Analysis of Special Education

A HISTORICAL ANALYSIS OF SPECIAL EDUCATION SERVICES IN

CONSERVATIVE CHRISTIAN SCHOOLS SINCE 1950

A thesis proposal submitted in partial fulfillment

for the requirements of the degree

Masters of Education

By

\section{KRISTI-LYNN CRAIG}

B.A. Early Childhood Education, Cedarville University, 2003

B.A. Special Education, Cedarville University, 2003

2010

Cedarville University 


\section{CEDARVILEUNIVERSITY \\ SCHOOL OF GRADUATE STUDIES}

August 4, 2010

I HEREBY RECOMMEND THAT THE THESIS PREPARED UNDER MY SUPERVISION BY Kristi-Lynn Craig ENTITLED A Historical Analysis of Special Education Services in Conservative Christian Schools since 1950 BE ACCEPTED IN PARTIAL FULFILLMENT OF THE REQUIREMENTS FOR THEDEGREE OF Master of Education.

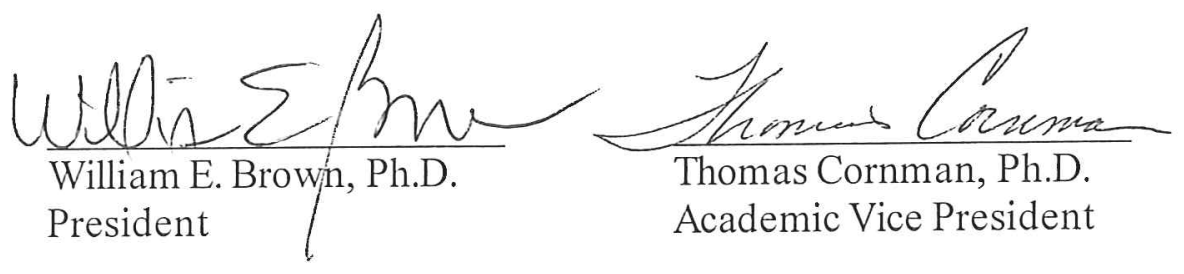

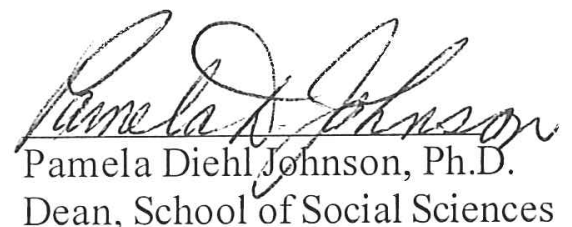

Dean, School of Social Sciences and Human Performance

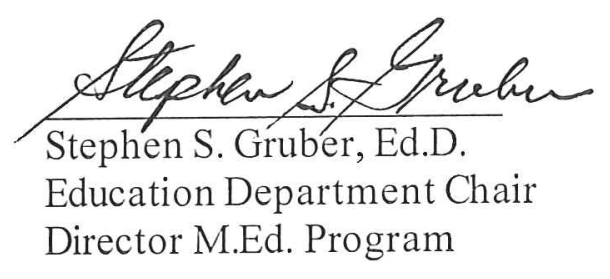

Education Department Chair

Ed. Program

\footnotetext{
Michaulwitiv

Michael Firmin, Ph.D.

Professor of Psychology

Thesis Advisor
} 
Running Head: A Historical Analysis of Special Education

\section{ABSTRACT}

Craig, Kristi-Lynn M.Ed., Education Department, Cedarville University, 2010. A Historical Analysis of Special Education Services in Conservative Christian Schools since 1950.

This study examines the historical progression of the availability of special education in Conservative Christian Schools in the United States since 1950. Due to the limited nature of research in this field, a historical analysis was used to better understand how the development of special education in Conservative Christian Schools compares to the development of special education in Public Schools. After analyzing the literature, four key turning points were identified. In addition, the significant roles of funding and Biblical support were examined. This thesis made recommendations for future, continued research and poses suggestions for Conservative Christian Schools to consider regarding the development of special education programs. Limitations to the study were noted. 


\section{A Historical analysis of Special Education}

\section{TABLE OF CONTENTS}

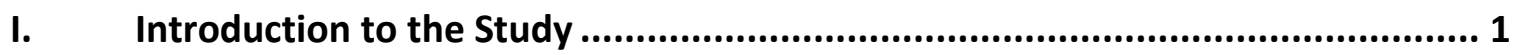

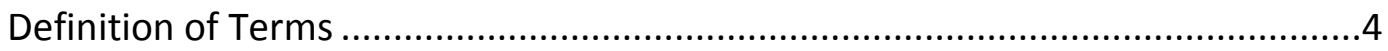

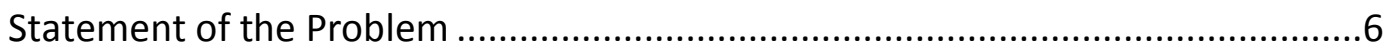

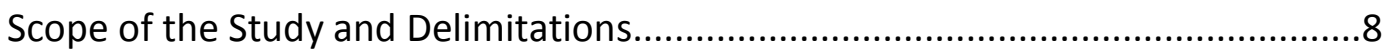

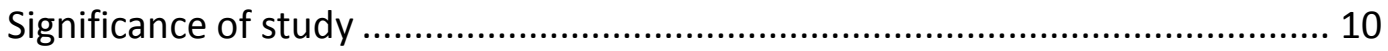

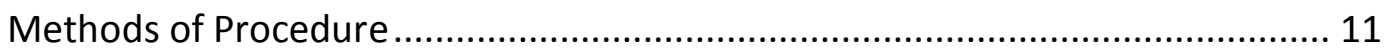

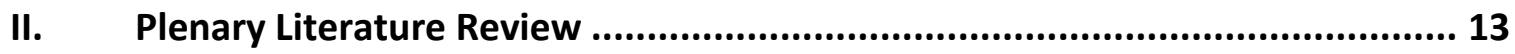

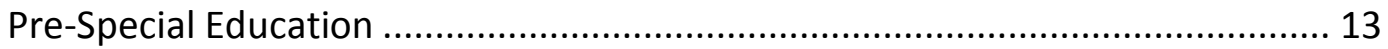

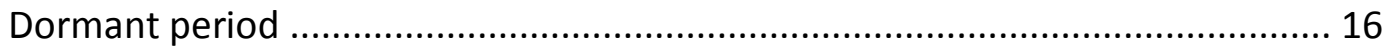

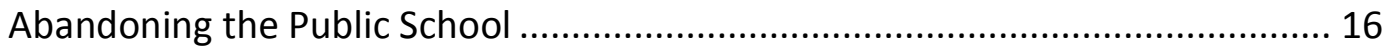

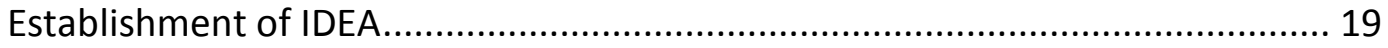

The State of Contemporary Conservative Christian School Special Education .... 24

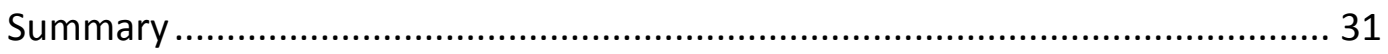

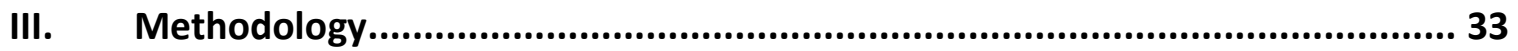

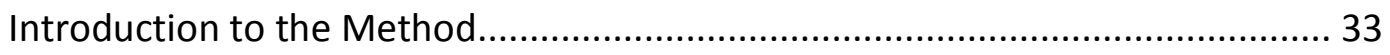

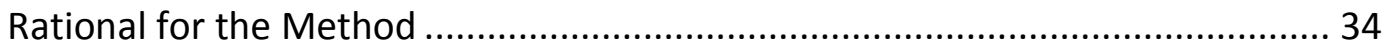

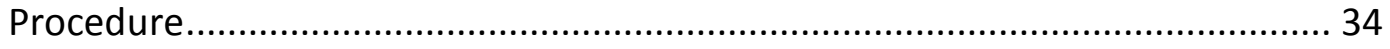




\section{A Historical Analysis of Special Education}

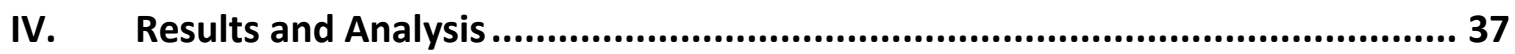

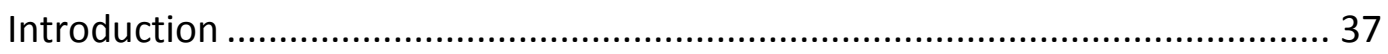

Description and Analysis of the Key Turning Points ........................................ 38

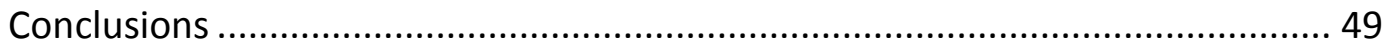

V. Discussion and Implications.......................................................... 54

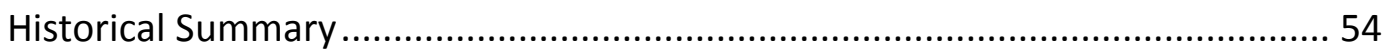

Biblical Integrative Component \& Implications .......................................... 56

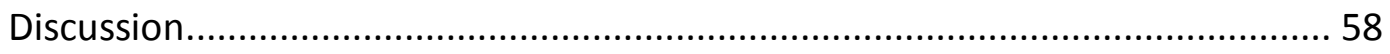

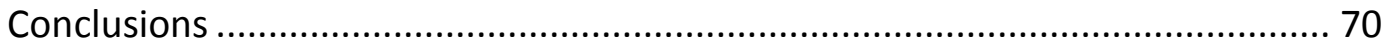

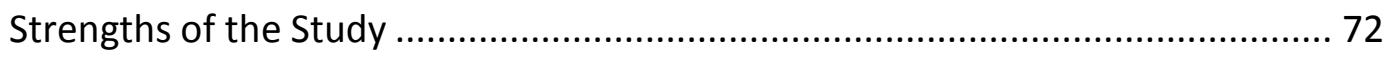

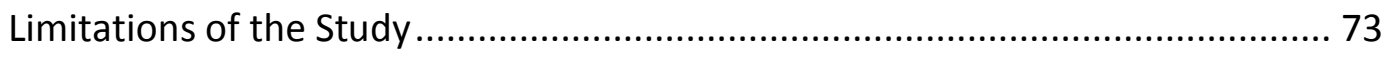

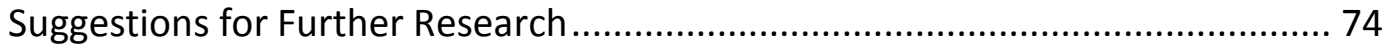

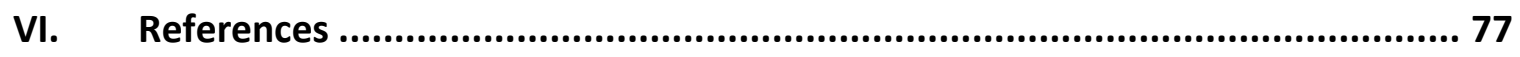




\section{A Historical analysis of Special Education}

Introduction

The 1954 Supreme Court decision in Brown v. Board of Education began the process of providing equal educational access to all students in the United States (Harding, 2009). Prior to this decision, the segregation of education included both race and students with disabilities. Brown v. Board of Education affirmed the idea that separate is inherently not equal. After a century of experience with residential institutions and wrestling with special education programs in the public schools, educators of children with disabilities acquired the background and opportunity to reflect on their experiences (Osgood, 2008).

Prior to Brown v. Board of Education and continuing through this pivotal decision, there were several events and laws that pushed special education into the public eye. While Brown was most influential, it was only one part of a series of events to draw the public's attention to special education. In the 1930's and 1940's, published observations by educators of special education brought a critical eye to the current status of special education as well as the needed change. As information exposed the condition of education provided to individuals with disabilities, advocates worked to create equal educational rights for students with disabilities. Seventy-two percent of children with disabilities were not enrolled in public school in 1950, but were either kept home or institutionalized (Anderson et. al., 2001a). It took several decades for special education in public schools to come into being. Section 504 of The Rehabilitation Act of 1973 states that discrimination cannot occur based on a child's disability (Osborne \& Russo, 2006). P.L. 94-142 (the Education of All Handicapped Children Act) passed in 


\section{A Historical Analysis of Special Education}

1975. This significant decision changed how public school children with disabilities were viewed and educated. When P.L. 94-142 was reauthorized in 1990, as P.L. 101-476, it was renamed the Individuals with Disabilities Education Act, or IDEA (Kluth, Villa, \& Thousand, 2001). IDEA required students to meet three requirements in order to receive special education services: (1) a child must be between the ages of 3 and 21, (2) a child must have a specifically identified disability, and (3) a child must be in need of specially designed instruction in the least restrictive environment (Osborne \& Russo, 2006). According to IDEA, the construct of least restrictive environment requires that, to the greatest extent possible, children with disabilities should be educated with their nondisabled peers and the removal of children with disabilities from the regular education classroom should only happen when education in regular classes cannot be reasonably achieved with the addition of aids and services (United States Department of Education, 2007). The two most recent laws passed that affect special education services are the No Child Left Behind Act (2001), which gave greater accountability to the education of students in both general and special education, and the 2004 reauthorization of IDEA (renamed IDEIA, the Individuals with Disabilities Education Improvement Act).

IDEIA, the most recent reauthorization of IDEA, attempted to clarify the responsibilities of the public school to children with disabilities placed by their parents in private schools. Public schools are required, by law, to seek out, evaluate, and collaborate with private institutions in order to ensure that children with disabilities are receiving the supports and helps needed to succeed (Drang and McLaughlin, 2008). 


\section{A Historical Analysis of Special Education}

Clarifying the relationship of private schools to funding for students with disabilities was another focus of the reauthorization. It is unclear why private schools report that low numbers of their students receive evaluations, diagnoses, and individualized education plans (IEPs) even when there are special education programs available for students within the private institution (Eigenbrood, 2005).

As legislation brought changes to special education programs in public schools, the growth of conservative Christian schools (independently) increased. In 1900, approximately 1.35 million students were enrolled in private schooling options, primarily Catholic institutions (Jones, 2008). Questions regarding the nature of schooling-specifically who should provide education to children in the United Statescaused conflict between states and some parents. The 1925 Supreme Court decision, Pierce v. Society of Sisters, established the right of parents to choose to have their children educated at a religiously affiliated institution (Russo, Osborne, Massucci, \& Cattaro, 2009). Prior to this decision, Oregon law had required that students ages 8-16 attend public school. The Supreme Court decision in Pierce was pivotal for the future development of private educational facilities.

Since the 1960's, evangelical Christians have been active in establishing alternative educational settings (Jones, 2008). Some protestant Christians shifted their loyalties away from public schools when they felt their beliefs and moral values were being taken out of school and replaced by a humanistic "secular religion" (Carper \& Layman, 2002). Supreme Court decisions in 1962 and 1963, removing prayer and devotional Bible reading from public schools, encouraged the growing dissatisfaction 


\section{A Historical Analysis of Special Education}

among many Christians. Between 1971 and 1981 the number of conservative Christian schools rose from 140,000 to 450,000 (Jones, 2008). By the year 2000 , approximately 5.9 million students were enrolled in private schooling options (this included homeschooling). The number of students enrolled in private institutions or homeschooled continues to rise, illustrating what many experts believe to be a growing lack of trust toward public education (Carper \& Layman, 2002). In this context, parents have claimed their right to choose how their children will be educated. However, the conservative Christian school option is often denied to students with disabilities.

Definition of Terms

Accelerated Christian Education (ACE). Founded in 1970, Accelerated Christian Education (also known as ACE or Schools of Tomorrow) provides Bible-based educational materials and supplies to its member schools (ACE, 2009).

American Association of Christian Schools (AACS). A non-profit organization founded in 1972 that provides advocative, legislative, educational programs and services to member schools as well as approximately 170,000 students (AACS, 2009).

Association of Christian Schools International (ACSI). A non-profit organization founded in 1978 that provides programs and services to assist Christian schools in approximately 100 countries and more than 1.2 million students (ACSI, 2009).

Child Find. Legislation that requires each school district to identify, locate, and evaluate children with disabilities as well as determine how those children will receive services for their disabilities (Rawson, 2003). 


\section{A Historical Analysis of Special Education}

Child with a disability. A child with a diagnosed impairment (which may be physical or mental) that interferes negatively with the child's learning (H.R. 1350, 2003).

Conservative Christian school. Schools that profess the evangelical commitments to educational programs, whereby conservative Christian perspectives are employed (Carper, 1984). According to NCES these schools that have a membership in one of the following organizations: Accelerated Christian Education, American Association of Christian Schools, Association of Christian Schools International, Oral Roberts University Education Fellowship (Broughman, Swaim, \& Keaton, 1994).

Free Appropriate Public Education (FAPE). Special education and related services that (a) have been at public expense, under public supervision and direction, and without charge; (b) meet the standards of the state educational agency; (c) include an appropriate preschool, elementary, or secondary school education in the State involved; and (d) are provided in conformity with the individualized program (H.R. 1350, 2003). Individualized Education Program (IEP). A written statement for each child with a disability that is developed, reviewed, and revised (United States Department of Education, 2007).

Individuals with Disabilities Education Act (IDEA). A reauthorization of P.L 94142, the Education for All Handicapped Children Act provides financial assistance to states for educating disabled students (Rawson, 2003).

Least Restrictive Environment (LRE). LRE states that children with disabilities are educated, to the maximum extent possible, with children who are not disabled (United States Department of Education, 2007). 


\section{A Historical Analysis of Special Education}

National Institute for Learning Development (NILD). An organization based in Norfolk, Virginia, NILD was established in 1982 to assist schools, organizations, and individuals in the development of programs for students with specific learning disabilities. Approximately 70,000 students have been served since 1982 (NILD, 2009).

No Child Left Behind Act (P.L. 107-110, NCLB). This Federal Act redefines the federal role of K-12 education by providing more accountability, local control, options for parents, and emphasis on proven teaching methods (No Child Left Behind Act, 2001).

Oral Roberts University Education Fellowship (ORUEF). ORUEF is a professional service organization founded in 1985 that provides networking opportunities and support services to Christian preschools, elementary, secondary and Bible schools (ORUEF, 2009). ORUEF formed the ICAA (International Christian Accrediting Association) in 1987 and enabled the ICAA to attain non-profit status in 1990 (ICAA, 2009). ORUEF utilizes the ICAA to provide accreditation to its member schools.

Section 504 (of the Rehabilitation Act of 1973). States that no handicapped individual in the United States shall, solely by reason of his handicap, be excluded from the participation in, be denied the benefits of, or be subjected to discrimination under any program or activity (including public school) receiving Federal financial assistance (United States Department of Education, 2009).

Statement of the Problem

The role of special education programs within the contemporary traditional school setting continues to change. Legislation, as well as new trends, traditionally has dictated the methods used to successfully meet the needs of children with disabilities. 


\section{A Historical Analysis of Special Education}

However, the role of special education programs within private schools is an area of continuing confusion. Legislation regarding private schools has been vague and, at times, unknown to those in private school settings. Government funding has been made available to public schools in order to facilitate special education programs, yet private schools struggle simply to maintain funding to educate the majority of students (those who do not have disabilities).

Conservative Christian schools began with the philosophy of offering an alternative to public school. At this time, the schooling population in public schools did not include children with disabilities. Consequently, conservative Christian schools began with a focus on educating students without disabilities. When P.L. 94-142 was passed in 1975, it required public school districts to provide children enrolled in private schools with special education and related services (Drang \& McLaughlin, 2008). However, the law was not clear in how the district would provide or fund those services nor did it require that private schools offer services to children with disabilities. Those conservative Christian schools which sought to provide services to children with needs faced many hurdles in funding. Each subsequent re-authorization of P.L. 94-142 has attempted to clarify the obligations of public school districts to students enrolled in private schools. Child Find was enacted to enable private schools, including conservative Christian schools, to collaborate with public schools in order to locate, identify, and give appropriate supports to children with disabilities. Conservative Christian schools have five options: 1 ) have parents pay therapists directly for the work they do, 2) increase tuition rates to all students in order to balance the cost to the 


\section{A Historical Analysis of Special Education}

budget of offering services to children with needs, 3) collaborate with other conservative Christian schools, 4) work with public schools or 5) offer no services. Some of the aforementioned options can be used together in order to more adequately meet student needs. However, even with this increased clarity, many conservative Christian schools seem unaware of their legal rights for children with disabilities (Eigenbrood, 2005).

Scope of the Study and Delimitations

I am studying special education programs offered by conservative Christian schools since 1950. The influence of key historical events and laws regarding current special education programs in conservative Christian schools will be explored in detail. The scope of the study involves the identification and explanation of specific legislative decisions that have played a marked role in the creation of special education programs in public schools as well as conservative Christian schools. Additionally, I will analyze the phenomenon, providing an appraisal of why participation historically has been so low and some potential options for how conservative Christian schools best might remediate the situation.

Although special education often overlaps with other related educational strategies, this study only concentrates on schools with special education programs. These programs have changed their structure and appearance over the decades but, for the purposes of this study, the common thread is that they addressed the needs of children with identified disabilities within a school setting, not an institution. Schoolaged youth are the focus for this study, although contemporary cultural traditions 


\section{A Historical Analysis of Special Education}

obviously impact the perception of special education. Therefore, the state of the culture is discussed in terms of its impact on special education programs in conservative Christian schools.

A discussion of special education programs in countries outside of the United States is not part of this research. Special education developed on both parallel and divergent tracks in other countries, so a comparison of foreign special education with the American special education system would require a comprehensive treatment beyond the scope of the present study. Cultural changes throughout history are not discussed in terms of how they affected other topics of school instruction because this study is limited to the interrelationship between culture and special education. Further, public, parochial, and private schools are not included in this research, although it would be an interesting topic for future study. This is because so many differences exist between private-public, private-religious, and religious-public schools, that it would not be feasible to survey those differences vis-à-vis special education, keeping the scope of the present thesis to a reasonable and manageable length. Only conservative Christian schools, as defined by NCES, will be examined.

The present study only focuses on events after 1950. Although it can be argued that special education existed prior to 1950 in America, this study will address events prior to 1950 only to lay a foundation for the events that happened after 1950 . The rationale for not giving coverage to pre-1950 special education is because generally, school-based special education did not begin until the mid-1900s in the sense that it 


\section{A Historical Analysis of Special Education}

exists today. Moreover, federal mandates and funding for special education only began after 1950.

Significance of the Study

According to a survey conducted by the Center for Special Education Finance, it costs approximately twice as much to educate a child with needs as it does a child without needs (Chamber, Parrish, \& Harr, 2004; Parrish et al., 2004). Consequently, some (M. Bryant, personal communication, April 28, 2010; Eigenbrood \& Eigenbrood, 1994) argue that current special education programs are completely dependent upon funding. They might insist that, while children with disabilities need support, the ability of the conservative Christian school to provide that support is severely limited due to funding. While agreeing that funding is a major component for special education programs, I suggest that this view is inconsistent with an understanding of the nature of current legislation as well as cultural perspectives regarding special education. History lays the foundation from which to examine the events that have affected the cultural perspective of special education. However, relatively little has been done to date in order to examine the history of special education in conservative Christian schools.

Various Christians have acknowledged the biblical support for special education and would not deny the need for special education programs in order to provide services to students with special needs (e.g. Schimmer, 1996; Vaughn, 1993). Many parents of children (with and without disabilities) who desire to have their children educated in a Christian environment feel that they have a right to that education. Organizations, such as the National Institute for Learning Development (NILD), provide 


\section{A Historical Analysis of Special Education}

support for parents who wish to have their children with special needs educated in a private setting. Parents have the opportunity to pay therapists directly for services to their children. Current legislation provides support for conservative Christian schools through the public school. However, a better understanding of this legislation may encourage more conservative Christian schools to provide better support for children with special needs, instead of making funding the dominant deterrent.

\section{Methods}

I examined the literature of special education programs in conservative Christian schools since 1950. I searched for available research from online databases such as Academic Search Complete, Ebsco, OhioLink, Education Full Text, Education Research Complete, PsychInfo, ERIC, Google Books, Google Scholar, and the Christian Periodical Index. I consulted books on the history of special education, the history of conservative Christian schools, and associations that play a key role in conservative Christian schools. Additionally, I researched ACE, AACS, ACSI, NILD, and ORUEF for information on their formation and response to special education needs within conservative Christian schools.

After consulting the breadth of research named above, I analyzed the literature in order to identify key turning points in the development of special education in conservative Christian schools. I have identified common themes throughout history and studied the source of each change which drew me to four historical events that were critical to the development of special education services within conservative Christian schools. Each of these key events was appraised by studying the impact on 


\section{A Historical Analysis of Special Education}

culture and the creation of policies. The key events led to the development of two views regarding funding special education services in conservative Christian schools. 


\section{A Historical AnAlysis Of SPECial EduCATION}

\section{Plenary Literature Review}

This thesis chapter will report a history of special education in American evangelical Christian school education. I begin by outlining the formulation of Christian education as a movement. Then I proceed to show special education's role in each of the subsequent developmental stages.

\section{Pre-Special Education}

Prior to the 1970's, Christians primarily participated actively in public school programming as noted in Jones' (2008) outline of the religious schooling development in the United States. In 1900 there were 15.5 million students enrolled in public school, while only 1.35 million (approximately $8 \%$ of the student population) were enrolled in private schooling options, primarily Catholic institutions. Overall, Protestant ministers supported public school, believing that it upheld and promoted Christian ideas (Reese, 1985).

In 1925, the state of Oregon challenged the right of parents to educate their children in a religious school. The state wanted to make public school mandatory for all children ages 8 to 21 . The court ruled that, while mandatory school attendance could be required, the state could not require that students attend public schools. This crucial decision, Pierce v. Society of Sisters, created the legal support for private schools to continue and develop (Randall, 1997).

In the early 1900s, pubic schools had little, formal special education programming. Acceptable and expected practice regarding students with disabilities, whether mild or severe, was to segregate them from their peers and educate these 


\section{A Historical analysis of Special Education}

students in separate classes and facilities. Children with disabilities were believed to excel more in a separate environment, as were their non-disabled peers believed to excel without the burden of students with disabilities sharing the classroom. Only $12 \%$ of students in public schools in 1948 were students with disabilities (Zettel \& Ballard, 1982). In the 1940 's this idea of separate is equal became increasingly questioned regarding special education practices (Winzer, 2002). Professionals and parents began to challenge whether or not if having children with disabilities educated in separate facilities and considered a burden on society was a profitable or appropriate perspective. Several seminal articles were published, encouraging professionals to actively begin participating in discussions regarding how students with special needs could be educated most effectively - some began to ask if the public school setting was actually where students should be educated (Osgood, 2008).

Contemporary writers of the time attempted to convey the challenges and joys of working with children with disabilities. For example, Pearl Buck (1950) published The Child Who Never Grew. Her book described the struggles of parenting and coping with a child diagnosed with severe mental retardation. Rogers (1953) wrote Angel Unaware. Writing the story from the perspective of her daughter with Down Syndrome, Rogers attempted to relay the heart ache and challenges of raising a child with disabilities. Blatt and Kaplan (1966) wrote Christmas in Purgatory. Using pictures with minimal commentary, they sought to depict the state of institutions for the mentally handicapped as accurately as possible. Writings, such as those by Buck, Rogers, Blatt, 


\section{A Historical Analysis of Special Education}

and Kaplan cogently challenged the way society had traditionally viewed children with disabilities and encouraged greater action to meet student needs.

Contemporary Christian writers of the time attempted to challenge the local church and conservative Christian schools with the task of meeting special needs. Bogardus (1963), Kemp (1957), and Towns and Groff (1972) described the needs of children with developmental disabilities as well as the needs of the teacher as they address those specific challenges. These authors sought to lay a foundation by which Christian churches could develop special education programs. Ebersole (1964) illustrated the need for Christian education for children with social disabilities, contrasting the needs of those with social disabilities to those with developmental disabilities.

During the 1950s, parents and educators began further to reevaluate the educational system in the United States. It was during these pivotal years that the Supreme Court's decision in Brown v. Board of Education was promulgated, asserting that separate is not inherently equal (1954). Brown specifically addressed the racial inequality evident in public schools. This decision not only challenged the contemporary status of the educational system of the United States (Osborne \& Russo, 2006), but also established the foundation for legislation that would address the participation of children with special needs in public schools (Anderson et al., 2001a). It was the Brown decision that prepared the way for equal access to students with disabilities in the public school sector as IDEA specifically references the Brown decision to provide support for the need for equality for students with disabilities. 


\section{A Historical analysis of Special Education}

Although public schools began to reevaluate how special education should be addressed, relatively little changed in this domain from 1954-1977. Consequently, education in general (whether public or private) was not completely addressing the needs of children with disabilities (Winzer, 2002). Parents watched the options for their children grow over the course of this period, yet pockets of significant involvement only occurred on the national level. The concrete development of special education programs, as it exists in contemporary public education, would not come until after the passing of P.L. 94-142 in 1975 (Braddock, 1987).

\section{Dormant Christian Schools}

From 1920 through 1960, approximately 150 conservative Christian schools were started with the intent to be an alternative to public education (Carper \& Hunt, 2007). A majority of protestant Christians during this time frame believed that the public school predominantly was a "Christian domain." As a result, most parents continued supporting public education, since their worldview saw the public school sector as being within both their relative control and purview of moral influence (Kniker, 1997). Much like the contemporary public schools of the time, Christian school administrators provided relatively few special education services.

\section{Abandoning American Public Schools}

The desegregation laws of the 1950s helped contribute to a rise in the development of conservative Christian schools (Ammerman, 1991; Parson, 1987). However, the preponderance of conservative Christian schools that were established during this time attribute their respective findings as being in response to busing laws of 


\section{A Historical Analysis of Special Education}

the 1950 s or with the intent to continue racial segregation (Lockerbie, 1980; Nordin \& Turner, 1980). The majority of Protestants continued supporting public education until the 1962 and 1963 Supreme Court decisions, removing prayer and mandatory Bible reading from school (Sikkink \& Hill, 2006). As a result, groups of Protestants began to develop an alternative to the public school system which they were viewing with a growing dissatisfaction. Beyond the Supreme Court decisions of the 1960s, problematic issues regarding curriculum in public schools began to grow (Park, 1980). Parents believed the public school was failing their children by teaching them from a humanistic view (LaHaye, 1983), specifically in the areas of evolution and sex education (Falwell, 1980; LaHaye, 1983). Parents desired an alternative to public schools that provided children with an education aligned with a Protestant worldview and cultural values fostering growth of the movement (Peshkin, 1986; Wilcox, 1992). Carper (1984) purports that the development of conservative Christian schools, with the resulting exodus of children from public schools, represented the first widespread secession from public schools since the establishment of Catholic schools in the nineteenth century.

The advent of conservative Christian schools in the 1960s brought about the formation of organizations in order to support these schools in the 1970s. Beginning in 1989, the National Center for Educational Statistics (NCES) collected data from private schools around the country. Broughman, Swaim, and Keaton (2008) identify four organizations that are specifically associated with fundamentalist and evangelical conservative Christian schools: AACS, ACE, ACSI, and OREUF. Overall, the role of these organizations is to provide member schools with legal representation, curriculum 


\section{A Historical Analysis of Special Education}

guidance, as well as teacher certification and training (AACS, 2009; ACE, 2009; ACSI, 2009; OREUF, 2009).

The American Association of Christian Schools (AACS) was founded in 1972. Considered one of the largest Christian school organizations, in 2008 AACS reported 820 schools, serving 99,456 students (Broughman, Swaim, \& Keaton, 2009). The Association of Christian Schools International (ACSI) was founded when the National Christian School Education Association, the Ohio Association of Christian Schools, and the Western Association of Christian Schools merged together in 1978. ACSI works with schools internationally, providing educational support to member institutions. Considered the largest Christian school organization, in 2008 ACSI reported 3,551 schools serving 651,017 students (Broughman, et al., 2009). Founded in 1970, by 1986 Accelerated Christian Education (ACE) had developed into an organization that started schools, provided curriculum to conservative Christian schools and homeschooling parents, and worked with schools globally. Also known as "The School of Tomorrow," by 2008 ACE reported 970 schools serving 41,385 students (Broughman, et al., 2009). Founded in 1985, Oral Roberts University Educational Fellowship (ORUEF) is the smallest of the four organizations identified by the NCES. Consequently, available information about this organization is more limited. By 2008, ORUEF reported 73 schools serving 13,724 students (Broughman, et al., 2009).

The growth of conservative Christian schools was continuous throughout the 1970s and 1980s. Dollar (1973) estimated that 3000 fundamentalist conservative Christian schools were in current existence in the United States and that they were 


\section{A Historical Analysis of Special Education}

growing at a rate of 100 per year. Carper and Hunt (2007) concur and estimate that between 8000 and 12000 conservative Christian schools have been started since the 1960s. Rose (1993) and Carper and Hunt (2007) agree that the growth of conservative Christian schools peaked in the 1990s followed by the advent of homeschooling.

\section{Establishment of IDEA}

The number of students with disabilities in public schools began to rise in the 1960 's. By $1968,38 \%$ of the children in public schools were considered students with disabilities, an increase of 26 percentage points from the $12 \%$ measured in 1948 (Zettel \& Ballard, 1982). A national movement began in the 1960s and continued through the 1970 's to change special education in the United States.

Several important laws were passed that affected special education practices in public schools. Section 504 of the Rehabilitation Act of 1973 stated that no person could be excluded from a program receiving federal assistance (McCormick, 1993). P.L. 94-142, also known as the Education for All Handicapped Children Act, allocated the funds necessary to ensure that no child with a disability was excluded from receiving a free, appropriate public education (Rawson, 2003). Even though the law was passed in 1975 and signed by President Ford, it was not implemented until 1977. Citizens did not fully expect the law to be wholly funded, as previous incentives had been under-funded (Giordano, 2007). Many of the changes in special education finally came as a result of parents who insisted on the reforms. P.L. 94-142 was facilitated by the public's changing perspective toward students with disabilities. Drang and MacLaughlin (2008) state that "IDEA is a law founded on the premise of individual rights and entitlements" 


\section{A Historical Analysis of Special Education}

(p.9). It was assumed that this legislation implicitly required mainstreaming (Hutchison, 2003) and that the individual rights of students with disabilities would be taken into account with mainstreaming. The Americans with Disabilities Act (ADA) passed in 1990 and required that reasonable accommodations be made for students with disabilities (Russo, Osborne, Massucci, \& Cattaro, 2009). Finally, the No Child Left Behind Act of 2002 put into place key elements to improve students' academic achievement, including students with disabilities (Osborne \& Russo, 2006).

In 1977, P.L. 94-142 was implemented and required local public schools to extend services to students with disabilities, 3.7 million students nationwide (Anderson et al., 2001a). The law mandated that public schools provide training and resources to teachers in order to provide an equal educational opportunity for students with disabilities. P.L. 94-142 was enacted, despite the cost and controversy over the services (Ravitch, 1983). Since the initial signing in 1975, P.L. $94-142$ has undergone several reauthorizations and was renamed the Individuals with Disabilities Act (IDEA). Each reauthorization has expanded the reach of services to children with disabilities. While the IDEA (and its reauthorizations) addressed children from birth to 21, the ADA of 1990 addressed the needs of adults with special needs in all walks of life.

Special education services continued to be implemented and integrated into all public schools throughout the 1970s and 1980s, but not without difficulty. The goal of the IDEA was to motivate schools in the direction of inclusion for their students with special needs (Harding, 2009; Kluth, Villa, \& Thousand, 2001). Due to the nature of the IDEA, school personnel sometimes were unsure of how best to implement the federal 


\section{A Historical Analysis of Special Education}

regulations and many of the debates surrounding special education initially focused less on ideology and more on funding (Osgood, 2008). Educators, professionals, and parents continued to question from where the funding would come in order to provide adequate services to students with disabilities (Ravitch, 1983). School administrators were being forced into a position of weighing what children needed for success against their respective budgets, thus forcing educators into a position of prioritizing services so that districts could cut those "less needed" items. Russo, Osborne, Massucci, \& Cattaro (2009) weigh-in on this discussion with the following:

Even more than three decades after the implementation of the original federal special education statue, Congress has still not come close to funding the IDEA's mandates fully. Increased federal funding for special education would result in more available funds to serve non-public school students with disabilities. ( $p$. 107)

According to IDEA, students enrolled by their parents in private schools do not have a right to a free and appropriate education (FAPE) or the same level of services that their public school peers receive. Rather, IDEA establishes the availability of funds from the public school district to students with disabilities in private schools. These funds are subject to the discretion of the public school district, which means that services may differ for private schools from state to state. Private schools students are, also, only entitled to a proportionate amount of federal funds, indicating that public school districts are not required to spend state or local funds on students from private

schools. Special education services can be provided on site at a private school (Agostini 


\section{A Historical Analysis of Special Education}

v. Felton, 1997; Peter v. Wedl, 1998; Zobrest v. Catalina Foothills School District, 1993).

If services are not provided at the private school, than the public school district must provide transportation to and from the special education services (Osborne, Russo, \& DiMattia, 1999). A thorough Child Find process is required for every student, whether in public or private schools (H.R. 1350, 2003). The Child Find process allows the public school to share with parents the services available to them through the public school as well as the options available through private schools. In this way the public school district allows parents to forgo their child's right to FAPE when choosing a private school.

As in public schools, private schools must provide an individualized plan for each child enrolled in their school who is formally identified as possessing a disability. This plan is most likely not called an IEP, as conservative Christian schools are not bound by the regulations of the IDEA, but fulfills the same purposes as an IEP in a public school (Eigenbrood, 2004). Since no child in a private school has the right to a specific service, the IDEA allows for the possibility that children enrolled in private schools may receive a different type of service, or even a different amount, than their public school counterparts.

Although the federal legislation makes provisions for private schools to receive assistance from public school sources, Christian schools generally do not avail themselves of the resources on a wide scale basis (Detwiler, 1999). Drang and MacLaughlin (2008) and Weber (2007) describe the responsibility of the public school, as illustrated in the IDEA toward private schools. They share that, although unclear in 


\section{A Historical analysis of Special Education}

the specifics, the IDEA requires districts to provide access to services for children with special needs in private schools. As such, it is the responsibility of the local school districts to provide a thorough Child Find process for all children living in their respective districts. Local school districts are regulated to provide these children, whether placed in public or private schools, with formal evaluations. Drang and MacLaughlin (2008) state that the low numbers of children receiving formal evaluations seems to be directly related to the lack of knowledge on the part of parents and staff of private schools regarding Child Find services available to them.

According to Detwiler (1999) and Provenzo (1990), the low number of students receiving formal evaluations could be related to an issue of worldview. Provenzo (1990) reports that conservative Christian schools often refuse to publically reveal the amount or kind of services they provide due to a desire to remain separate from governmental influence and control. Gunn (2006) states that administrators, parents, and school board members are concerned that allowing the government any foothold into their respective institution potentially might undermine the very reasons behind starting a private, religious school. Some parents fear that the State will attempt to control the way their children are educated and infiltrate curricula with secular ideals.

As the national cultural view regarding children with disabilities changed from neglect to acceptance, parents continued to demand equal educational opportunities for their children with disabilities. Deborah Zimmerman began developing a program to use in a traditional classroom setting in order to meet student needs (NILD, 2009). This program became the foundation for the National Institute of Learning Development 


\section{A Historical analysis of Special Education}

(NILD), which was established in 1982 in order to assist conservative Christian schools in meeting the needs of students with disabilities (NILD, 2009). The organization reportedly has served 70,000 students since it was formed in 1982 (personal communication, NILD representative, 2009). NILD adopts a "remedial" model of LD (learning disability) intervention and services that are offered on a fee-for-service protocol. School administrators who have NILD trained "therapists", as a part of their school staff, advertise their work in order to encourage parents of children with disabilities to attend their school. The "therapy" of the program often is offered via one or two sessions per week, for which parents must pay, in addition to regular tuition. In this way, schools are able to offer limited services to students with disabilities, in spite of a lack of funding for a comprehensive LD program.

\section{Contemporary State of Evangelical Christian Schools}

The 1980s brought a renewed call to special education by Christian writers. For example, Grammer (1981), Groff (1986), Hawley (1981), Hight (1986), and Malone (1986) addressed the needs of children with disabilities. As did the Christian authors of the 1950 s and 1960 s before them, these authors sought to challenge Christian schools to educate those with special needs as well as lay a foundation for the future development of such programs. This portion of chapter two will examine current research as well as the status of special education services in six Christian school organizations. The six Christian schools organizations were selected on the basis of the following: (1) identified by NCES or (2) identified in the literature as substantial curriculum providers to evangelical Christian schools. 


\section{A Historical Analysis of Special Education}

\section{Current Practice}

Relatively little information is available regarding the current state of special education programs in conservative Christian schools. The three most current published studies were conducted by Sutton (1990), Sutton, Sutton, and Everett (1993), and Eigenbrood (2005). In addition to these studies, some of the previously mentioned Christian school organizations websites have begun to offer more general information regarding their responses to special education services.

Sutton (1990) provided an account of ACSI member schools in the United States and the special education services offered. The researcher analyzed the school descriptions of 2,347 ACSI associated Christian schools. While information was limited, a section of the ACSI member directory notes whether schools offer special education services. Sutton found that $8 \%$ reported themselves to offer special education programs. The researcher found that a greater number of special education programs existed in schools with student enrollments of more than 100.

Sutton, et al. (1993) provided an account of AACS member schools and the special education services offered throughout the United States. From a random selection of 169 schools throughout the country, the researchers received initial responses from 87 schools. Of those, only five were found to have formal special education programs offered to their students. Moreover, the researchers found that only two of the eight teachers providing special education services in the conservative Christian schools had a special education degree. The authors also reported that formal special education programs were nearly non-existent in conservative Christian schools, 


\section{A Historical Analysis of Special Education}

primarily as a result of funding, but also due to a perspective that evangelical Christian schools are not legally obligated to offer those programs.

Eigenbrood (2005) surveyed private faith-based schools and public schools to compared services offered. The researcher reported that, while $83 \%$ of the administrators of faith-based schools indicated they hired a part-time teacher to provide resource room services, most public schools (87\%) had a full-time teacher assigned to their respective resource room programs. Each student in the public schools surveyed had been formally identified as needing special education services as the result of a disability, while only $40 \%$ of the students in the faith-based schools had been officially identified as eligible for special education services. Contrary to federal guidelines, students served in faith-based schools had not been formally identified by standardized procedures. Moreover, $90 \%$ of the faith-based school administrators surveyed shared that most (or all) of their students with disabilities did not have IEPs (or an equivalent document). Eigenbrood (2005) likewise noted that, routinely, few students had been identified as having a disability in faith-based school resource rooms. While $95 \%$ of the public schools reported that at least some of their students had received a full psychoeducational evaluation, only $40 \%$ of faith-based schools reported the same type of evaluation had been given to at least some of their students. In addition, all public school teachers in the survey sample had a state-issued teaching certificate in special education, while only one third of the faith-based special education teachers possessed the same licensure. Eigenbrood (2005) emphasized that, if local public schools were to decide to use some of their allocated IDEA monies to support services to a child with 


\section{A Historical Analysis of Special Education}

disabilities in these faith-based schools, then the money would not quality for disbursement due to the lack of training on the part of the Christian school educator.

\section{Curriculum Providers}

The three curriculum providers with the widest distribution to conservative Christian schools are A Beka, ACE, and Bob Jones University Press. The A Beka curriculum was developed in the 1970 s by Arlin Horton and his wife, Beka Horton. Their desire was to develop a curriculum grounded in Biblical truth that fulfilled the needs of conservative Christian schools (A Beka, 2010). A Beka representatives purport (D. Beck, personal communication, May 18, 2010) that they do not take materials that are currently being used in public schools and add Bible verses to the curriculum in order to make it more Biblically based. Rather, A Beka researchers have developed curriculum that is Biblically based by conducting their own research and writing their own books with their Biblical perspective woven throughout the narrative. Each of the major Christian school textbook publishers follows this protocol.

Researchers with A Beka utilize Pensacola Christian Academy to aid in the development of curriculum for Christian schools. The A Beka curriculum is presented in a high structured format that guides both teachers and students using step-by-step explanations and daily workbook assignments. Parents and teachers are responsible for the adaptations and modifications that would need to be made in order to suit the curriculum to the needs of students with specific disabilities. A Beka also directs schools to connect with the appropriate professionals (certified special education teachers, 


\section{A Historical Analysis of Special Education}

therapists, etc.), should they wish to develop a more extensive special education program (D. Beck, personal communication, May 18, 2010).

Bob Jones University Press (BJU Press) likewise sells curricula to conservative Christian schools. While also providing materials grounded in Biblical truth, they stress that the teacher, rather than the textbook, is the most important factor to convey that truth (Bob Jones University Press, 2010a). Special education curriculum is not offered through BJU Press, although BJU press staff indicate that they often direct parents and educators to contact homeschooling consultants when special education enquiries are made (Bob Jones University Press, 2010b). BJU press' homeschooling consultants talk with parents who are homeschooling (as well as schools) regarding modifying BJU Press curriculum in order to tailor it to individual student needs. Ms. Pam Levan, a BJU Press homeschooling consultant, possesses a master's degree in special education. She (P. Levan, personal communication, May 17,2010 ) shared that approximately $25 \%$ of her calls are specifically related to modifying curriculum for students with special needs. Ms. Levan assists parents and schools, directing them to a number of resources: websites that will read material for students, programs that will write what a student speaks, Christian therapists and psychologists (if needed), and the "distance learning" curriculum through Bob Jones University Press. Parents are encouraged to have a professional provide a formal diagnosis for the struggling child (P. Levan, personal communication, May 13, 2010).

ACE offers curriculum to evangelical Christian schools as well as homeschooling parents. Rose (1993) described the curriculum as potentially useful and adaptive for 


\section{A Historical Analysis of Special Education}

students with special needs, due to its independent structure. ACE utilizes a flexible model of instruction in which students complete materials at their own respective pace (ACE, 2009). In fact, student packets are called PACEs (pre-packaged ACE material). Students complete up to 60 PACEs each year, correcting and checking themselves throughout the year. Each PACE has quizzes and tests that measure student progress. Adult supervisors for the ACE program at a given conservative Christian school check the PACE quizzes to ensure that students are ready for the PACE final test. All materials are sent to an ACE trained representative who verifies the progress of the student and passes the student onto the next grade level. Students have the opportunity to proceed through material as quickly or slowly, as educationally prudent for students' respective optimal learning. A certified teacher is not needed to deliver the ACE content in the PACEs since students are expected to complete assignments and appropriately evaluate their personal mastery of topics. Adults are supervisors of the rooms where students progressing independently and help to maintain an environment conducive for students to work through materials alone. ACE does not have current data regarding the number of schools offering special education (personal communication, April 22, 2010).

\section{Conservative Christian School Organizations}

Conservative Christian school administrators sometimes do not report information publicly regarding special education services in their schools, fearing that it potentially could lead to government regulations or intrusion (Reese, 2004). As a result, fundamental Christian school organizations often have a difficult time acquiring specific information about member schools (AACS secretary and ORUEF secretary, personal 


\section{A Historical Analysis of Special Education}

communications, 2010). Of the four organizations queried, only ACSI routinely requests that schools report whether they service children with special needs. By 2010, ACSI reported 273 , or $8 \%$, of its member schools offered special education programs (ACSI directory, 2010). In order to encourage schools to modify material for students with disabilities, special education speakers are hosted at ACSI conferences each year (personal communication, Jane Schimmer, 2010).

ACE does not request information regarding special education services from schools that utilize the ACE curriculum (A. Mossman, personal communication, April 22, 2010). One stated reason that ACE does not request this information from its consumers is due to variety of programs to which ACE provides curriculum homeschooling parents working alone, homeschooling parents working through the Lighthouse Christian Academy, and conservative Christian schools. Individuals and schools are responsible to modify curriculum for students with disabilities, if the respective schools choose to use them for that purpose. ACE provides support through workshops and special education speakers hosted at ACE conventions, and by working with individuals who request help is modifying and adapting curriculum for students with disabilities (A. Mossman, personal communication, April 22, 2010).

AACS does not maintain records regarding the number of schools that offer special education services (K. Kowalcyk, personal communication, April 28, 2010). AACS is an organization comprised of individual state organizations. These local organizations reportedly do not maintain records of schools with special education services. While approximately 800 institutions hold membership with AACS (and their respective state 


\section{A Historical Analysis of Special Education}

organizations), I was only able to locate 6 schools (nationally) that offer special education services. While other schools may exist, the lack of networking format on the part of AACS in this domain makes it very difficult to identify schools that currently posses LD remediation programs, apart from contacting each of the 800 member schools.

While ORUEF does not maintain records regarding the presence of special education programs within its member schools, the accrediting branch (ICAA) routinely connects with each member school. The organization is relatively small (around 100 schools) and approximately 30 of those schools offer formal special education programs (D. Peal, personal communication, May 25, 2010). Donald Peal (personal communication, May 25, 2010), director of ICAA and ORUEF, believes that close to $95 \%$ of the member schools offer services to students with identified disabilities when methods other than formal special education programs (i.e., certified special education teachers, resource rooms, etc.) are taken into account (i.e. dependent upon the teacher to modify work). Peal's statement implies an acknowledged need for special education and also leads the reader to question the validity, since proper documentation is lacking.

\section{Summary}

An overview of special education in conservative Christian schools provides an essential foundation for understanding the current state of special education in conservative Christian schools in America. Prior to 1950, special education programs were virtually non-existent in the public and private sector. Overall, special education, 


\section{A Historical Analysis of Special Education}

as known in its current, formal structure, was non-existent in evangelical Christian schools prior to 1950. The homecoming of World War I and World War II veterans began to raise the awareness of society regarding people with disabilities. Literature of the 1950s illustrates that connections were made between adults with disabilities to children with disabilities. Movements began during the 1950s and 1960s that would change the course of special education.

The establishment of IDEA in 1975 was a time of significant change for special education. Conservative Christian schools, in response to the "secularization" of public schools, were being established nationally at a rate of one per day (on average). While Christian administrators and parents were abandoning the public school, public schools were being required by law to establish special education programs. This era saw substantial growth in conservative Christian schools and, separate from the conservative Christian school movement, in special education.

The growth of the evangelical Christian school movement reached a plateau around the time that the homeschooling movement began to flourish in the United States. It is during this period that evangelical Christian schools seemed most to wrestle with funding special education programs and the Biblical support that many educators believed existed for the establishment of special education programs in conservative Christian schools. 


\section{A Historical analysis of Special Education}

\section{Methodology}

It is by knowing the history of an event that the current standing of society can be understood (Mertens, 2005). The historical, cultural, social, and economic conditions surrounding an event also must be studied to create a complete understanding of a phenomenon's overall impact. Historical analysis takes into account each of these conditions in order to form a comprehensive picture of a given event. An analysis of the complete picture allows for conclusions to be drawn and generalizations inferred from the historical events.

Historical analysis, a form of Archival research, evaluates events from the past and interprets those events by taking into account the multiple points of view presented (Johnson \& Christenson, 2008). Cohen, Manion, and Morrison (2007) describe the researcher as an archeologist who interprets past events by the traces that have been left. Historical analysis also offers the opportunity to evaluate the past in light of what is now known. The researcher has the unique opportunity to make connections and see the development of ideas with the advantage of being removed from the event.

While involving the accumulation of facts, dates, figures, and descriptions, historical analysis also involves some interpretation (Johnson \& Christenson, 2008). The researcher must synthesize the information and make judgments regarding the information, while maintaining as reasonably objective a viewpoint as possible. As a result, conclusions can be drawn that both affirm historical findings as well as address future consequences. 


\section{A Historical ANALYSIS OF SPECIAL EDUCATION}

\section{Rational for the Method}

The present research question is, "What key events contributed most notably toward the underdevelopment of special education programs in conservative Christian schools?" A review of the available empirical literature shows that conservative Christian schools have not developed special education programs in response to the changing climate toward special education over the last 60 years. Historical analysis encourages the appraisals of events in a holistic manner. Ideally, historical research should bring to light new information or fresh perspectives. This thesis brings a novel perspective to the study of special education in conservative Christian schools and brings to light successful practices that counter the hindrance of funding.

\section{Procedure}

The present document study examined the history behind the conservative Christian school and special education movement. Conducting the present research involved exploring primary and secondary sources in order to locate key events that contributed to the current state of special education in evangelical Christian schools. I performed an extensive search of online databases (including PsychInfo, ERIC, Education FullText, and EBSCO Host) as well as Google Scholar in order to locate as many sources as possible. An extensive search on OhioLink provided additional sources as well as the Christian Periodical Index.

In addition to exploring written records, I spoke with individuals who were involved in the development of special education programs in conservative Christian schools, as well as the development of conservative Christian schools who work 


\section{A Historical Analysis of Special Education}

exclusively with students with special needs. I also spoke with representatives in each of the organizations studied. Furthermore, I contacted approximately 150 conservative Christian schools to gain insight into their perspective regarding special education services. This provided personal insights and additional details that were not part of formal written records. Secondary sources also supported the research process, including periodicals, newspaper clippings, and other reports that expanded my understanding of the history of special education in conservative Christian schools in America. University resource librarians provided invaluable aid in helping to ensure I did not overlook potentially useful data sources. In all, I thoroughly explored the writings of conservative Christian schools regarding special education endeavoring to understand the cultural Christian perspective regarding special education as well as the approaches taken by conservative Christian schools.

An analysis of all the data showed four eras that seemingly marked changes in cultural perspectives regarding special education in conservative Christian schools. They are the Dormant Christian Schools, Abandoning Public Schools, Establishment of IDEA, and Contemporary State of Conservative Christian Schools. The divisions were not arbitrarily chosen. They were derived because of common themes that bound certain decades together in reference to the development of special education in conservative Christian schools. While each era played a key role in propelling special education forward, not all events were equally important with reference to their respective impacts. The unique element in the present thesis is how I threaded the various causes, showing their overall impact, and also the analysis I provided within each era. 


\section{A Historical Analysis of Special Education}

An event qualified as a key turning point if it significantly influenced the culture of that particular period, as well as having the quality of exercising a continuing influence on the subsequent development of special education in conservative Christian schools. Following the identification of key turning points, the final step of this study involved a discussion of the implications of the findings. What can be discovered from history that will assist in making prudent future decisions regarding special education in conservative Christian schools? In the past, individuals and groups have either denied or supported special education programs based on funding and Biblical support. This thesis separated the two and made recommendations for the future. This final step in historical analysis sought to make the study practical, in addition to contributing to the academic and theoretical nature of present discussions among evangelical Christian school leaders. 


\section{A Historical AnAlysis Of SPECial EduCATION}

\section{RESULTS AND ANALYSIS}

Since 1950, four key events have provided a catalyst for the limited development of special education in conservative Christian schools. These same events also offered foundational underpinnings for the development of two major views of special education in conservative Christian schools. Each turning point set major changes in motion, but the respective changes often reached far beyond the special education debate. Some of the events contributed to the development of special education in conservative Christian schools while others distracted from forward development.

As previously noted, an event qualified as a key turning point if it significantly influenced the culture of that period and the development of special education in conservative Christian schools. Contemporary society and policy implications were considered when defining a turning point. The salient events were based on affirmative responses to these questions:

- Were important policy or social decisions made as a result of the event?

- Did the event influence the current or future zeitgeist?

- Did the event have social and political implications for the implementation of special education in conservative Christian schools?

The four resultant major turning points are as follows: (1) Brown v. Board of Education, (2) the Supreme Court decisions of 1962 and 1963 removing prayer and Bible reading from public schools, (3) the passing of the Individuals with Disabilities Education Act (IDEA) and, (4) the rise of homeschooling among conservative Christian parents. This 


\section{A Historical Analysis of Special Education}

chapter explores the unique characteristics of the four historical turning points and the role each played in shaping the development of special education in conservative Christian schools.

\section{Description and Analysis of the Key Turning Points}

The zeitgeist created by Brown v. Board of Education. The first major historical event that laid the foundation for special education in conservative Christian schools involved the homecoming of veterans with disabilities from World War II. The cultural climate was ripe for reform during the early part of the $20^{\text {th }}$ century as information regarding the horrific status of institutions for the disabled became more widely known. Families of veterans with disabilities did not want to see impaired veterans placed in institutions, particularly ones that were filthy and inadequately staffed (Palmer, 1961).

While not a direct result of the return of veterans with disabilities, this event contributed to the changing perspective culturally regarding children with disabilities. It was as this desire for equality in education grew for those individuals outside of the mainstream that the 1954 Supreme Court decision in Brown v. Board of Education mandated racial equality in education (Zettel \& Ballard, 1982). In this decision the Supreme Court affirmed the idea that separate is not equal. The Supreme Court decision encouraged educators to begin evaluating education in light of equality among its recipients. While the Brown decision mandated racial equality in the education of children, it also reached beyond racial tensions to the circumstances of children with disabilities (Harding, 2009). Parents of children with disabilities saw Brown as the catalyst that would bring equality to education for all children. While the view of adults 


\section{A Historical Analysis of Special Education}

and children with disabilities began to change, the conservative Christian community began to spearhead changes in the education of children with disabilities. Two conservative Christian schools were started with the exclusive focus of educating children with disabilities: Elim Christian Services and Shepherd Ministries.

Elim Christian School and Life Training Center for the Disabled, a member of Christian Schools International, was founded in 1948 by Rev. and Mrs. William Masselink. The Masselinks had a son, Paul, who was born with Down Syndrome and decided to begin teaching Paul at home. Rev. and Mrs. Masselink approached the area churches asking if, in partnership, they would help to support a school for children with special needs. The churches agreed and Elim Christian School began in Chicago, IL. By 1969, hundreds of children had been educated at Elim Christian School (Swierenga, 2005).

Shepherds Ministries, located in Union Grove, Wisconsin, began in 1957. Garfield Baptist Church listened to the desire of one of their families and began a ministry to parents of children with mental retardation. Founded in 1964, Shepherds Ministries began as a school and boarding home for 36 children with developmental disabilities. Shepherds transitioned to services for adults with physical and developmental disabilities when public education began to provide more services to children with disabilities (Shepherds Ministries, 2010). Shepherds Ministries is independent of any Christian school organization.

Government funding was not available for special education services in public or private schools during this period of time. As a result, Elim Christian Services and 


\section{A Historical analysis of Special Education}

Shepherds Ministries charged tuition to parents for the services provided. Parents of children with disabilities wanted their children to have an equal opportunity to education, which was not being given in public schools or in institutions for the disabled. The creation of these two schools allowed for their students to be educated, but failed to address the aspect of separation from other students established in the Brown decision.

\section{The Supreme Court decisions of 1962 and 1963 removing prayer and Bible}

reading from public schools. The second major historical event that laid the foundation for the development of special education in conservative Christian schools involved the Supreme Court decisions in 1962 and 1963 removing prayer and Bible reading from public schools. These two decisions were pivotal to the growth of conservative Christian schools. Conservative Christian parents believed that public schools generally were influencers for protestant beliefs. When the Supreme Court ruled to remove prayer and Bible reading, Christian parents became concerned that public schools were no longer purveyors of Christian values. As a result, Christian parents began to actively pull their children from public schools and place them in conservative Christian schools. Evangelical Christian schools during this time period were expanding nationally at an average rate of one new school per day (Carper, 1984).

The reactionary nature of conservative Christian schools created a dilemma in their policies. While parents were unhappy with public schools, they could not afford to pay exorbitant prices for private schools. Conservative Christian school administrators needed to examine what costs would be necessary for the respective school's survival. 


\section{A Historical Analysis of Special Education}

Administrators looked for legitimate means to cut costs, including protocol such as using cast-off textbooks from area public schools in lieu of purchasing new equipment, hiring teachers that were not certified by the state, offering only the basics in the instruction of reading, writing, math, science, history (Reese, 1985). Special education services were not seen as a priority; starting and maintaining the conservative Christian schools' fiscal standing was the priority (Sutton, Sutton, \& Everett, 1993).

With private institutions available for enrolling children with disabilities, albeit some were understaffed and filthy (Blatt \& Kaplan, 1966), the focus of conservative Christian schools was to continue offering education to their students, not to develop special education services. It was during this time that some parents began to speak out again this general viewpoint towards students with disabilities. A growing number of conservative Christian parents wanted their children with disabilities to have the same opportunity to a Christian education as did their children without disabilities.

While Elim Christian Services and Shepherds Ministries were offering services to children with special needs, these two schools were limited. Children in the area surrounding these two schools were being serviced effectively, albeit still separated from their non-disabled peers. Children with disabilities in other parts of the United States, however, did not have access to the same opportunity for services. Parents, both Christian and otherwise, became more verbal in their desire for appropriate services for their children with disabilities.

One prominent conservative Christian school established during this time was The Little Light House (LLH). LLH, an ORUEF member, began in 1972, resulting from the 


\section{A Historical Analysis of Special Education}

dedicated desire of two young families with visually impaired infants (Little Light House, 2010). With locations in Oklahoma, Mississippi, and Texas, LLH serves children, ages birth through age 6 , on an individual basis. All children receive services tuition-free, as LLH is solely supported through contributions and fundraising, accepting no government funding. LLH serves children with physical and development disabilities (J. Winfrey, personal communication, May 23, 2010).

Widespread governmental funding for special education services was not made available to any schools until 1973. The Rehabilitation Act of 1973 established the right of individuals with disabilities to fully participate in society as equal citizens. Section 504 of the Rehabilitation Act stated that no one could be discriminated against or denied access to programs supported by the government, including public school. The Rehabilitation Act also established the key role that the government would play from this point forward; specifically in providing funds to support programs that would continue to integrate adults and children with disabilities into society. Private institutions were not offered funds at this time since the focus of the Rehabilitation Act was on public programs. Therefore, as conservative Christian schools continued to develop in response to the growing distrust that Christian parents had for public schools, they also struggled with funding (Sikkink, 2001). Special education services were not a priority, especially as public services became more available to families.

It was during this time period that some Christian authors began to write about the Biblical support for offering special education services (Borgardus, 1963; Ebersole, 1964; Kemp, 1957; Towns \& Groff, 1972). It is apparent in the literature that Christians 


\section{A Historical Analysis of Special Education}

did not deny that Biblical support existed to include children with disabilities in conservative Christian schools (Palmer, 1966). However, the problems of funding often trumped the theoretical beliefs that educators and administrators held. Very little action was taken in developing special education services in conservative Christian schools during this time frame.

The passing of the Individuals with Disabilities Education Act (IDEA). After the Rehabilitation Act of 1973, government officials began to create IDEA to specifically address the needs of children in public schools. The IDEA, which specifically references the Brown decision, marked a key turning point in special education in public schools that significantly affected how special education would be viewed from that point forward. While not mandating that private schools provide special education services, IDEA put in place supports to encourage the integration of students with disabilities into all schools.

Conservative Christian schools were not required by IDEA to provide services to students with disabilities. However, IDEA did allocate funds for the use of private schools through the public schools (Eigenbrood, 2005). The IDEA did not require that students in private schools receive the same educational supports as their public school peers, but did require that public and private schools work together to provide as many supports as possible to students with disabilities in private schools (Drang \& McLaughlin, 2008).

IDEA has been reauthorized several times and each reauthorization has attempted to clarify how public and private schools should work together without 


\section{A Historical Analysis of Special Education}

compromising the separation of church and state (Eigenbrood, 2004). While some compromises need to be made (e.g., the working together of public and private officials regarding when, how, and where supports will be provided), both public and private schools have been, at times, unwilling to make those compromises. Specifically on the part of some conservative Christian schools, school administrators have refused any government funding that would provide for special education services, fearing the additional requirements and governmental oversight that eventually may come when accepting those funds (Provenzo, 1990).

While IDEA allocated some funds toward special education services in conservative Christian schools, a lack of special education programming continued in conservative Christian schools. Potential compromises attached to receiving government funding and a lack of understanding regarding IDEA have led many schools to continue without special education services, despite a belief in the need for those services (Oosterhuis, 1998). As most conservative Christian schools failed to provide the supports needed for children with disabilities, some Christian parents sought to establish specialized schools in order to meet the needs of their children with disabilities. Elim Christian Services, Shepherds Ministries, and Little Light House continued their work in Illinois, Wisconsin, and Oklahoma, respectively.

Pastor John Vaughn was motivated to begin Hidden Treasure Christian School (HTCS) in Greeneville, SC because of the inability of existing local Christian schools to meet the educational needs of his 5-year-old daughter. In 1981, the doors of HTCS opened to Pastor Vaughn's 5-year-old daughter and a 13-year-old teenager with 


\section{A Historical Analysis of Special Education}

cognitive delays. HTCS, a member of AACS, serves children with physical, developmental, and learning disabilities (Hidden Treasures, 2010). HTCS offers up to $\$ 5500$ in scholarships, available through donations made by organizations, churches, and individuals, to help parents with tuition costs (Hidden Treasures, 2010).

Gateway School and Learning Center (GSLC) began with seven students in 1983. Marilyn Anderson, a former Christian school teacher, saw a need to teach students with dyslexia, a misunderstood disability in the 1970s (Vincent, 2006). Anderson's focus was to teach to the individual and not the curriculum. In 1987, Nancy Ketchum joined Anderson, becoming a co-founder for GSLC. By 2010, the enrollment at GSLC was 37 students in $1^{\text {st }}$ through $12^{\text {th }}$ grades. GSLC, located in Anchorage, Alaska, is a member of ACSI.

Master's Academy, located in Duncanville, Texas, was established in 1988 by a mother and former Christian school vice-principal, Elderine Wyrick (Vincent, 2006). Wyrick could not locate a local Christian-based program that supported her two sons, both with learning disabilities, in achieving their potential. The first year began with 16 students in Wyrick's living room and ended with 26 students and a new location, Haswell House. Master's Academy, a member of ACSI, services students who are two years behind academically and diagnosed with a learning disability.

The previously mentioned schools reflected a growing desire among conservative Christian parents. Some Christian parents were willing to pay tuition in order to provide a Christian education for their children with disabilities. Seeing the need for quality special education services in conservative Christian schools, Deborah 


\section{A Historical Analysis of Special Education}

Zimmerman began developing a program to use in a traditional conservative Christian school classroom setting in order to meet student needs (NILD, 2009). This program became the foundation for the National Institute of Learning Development (NILD), which was established in 1982 in order to assist Christian day schools in meeting the needs of students with disabilities (NILD, 2009). NILD adopts a "remedial" model of LD (learning disability) intervention and services that are offered on a fee-for-service protocol. Students with disabilities are offered two sessions a week, 80 minutes per session, where therapists attempt to correct the learning disabilities. Zimmerman believed that dyslexia could be corrected and did not seek to teach students overcompensation skills but rather sought to teach children how to remediate their disability.

Some of the strategies used during this time for children with disabilities had come as a result of the work of Samuel Orton, a neurologist and psychiatrist. Orton was the first to document the disability of dyslexia (Yost, n.d.). He worked with a 16 year old boy who could only read at a first grade level and developed a strategy for instruction to allow the boy success in reading. Anna Gillingham, and educator and psychologist, read the work of Orton and wanted to put his suggested strategies into more widespread practice. In 1931 Orton and Gillingham began a professional collaboration that resulted in the development of the Orton-Gillingham Approach. Gillingham trained teachers in the method and observed, not only the teachers but also, student success with the method. The Orton-Gillingham Approach became the base for several other teaching methods: the Alphabetic Phonics Program, the Hermon Method, the Slingerland 


\section{A Historical analysis of Special Education}

Approach, and Wilson Reading Program (Friesen, 2002). Each of these methods is

language-based, multisensory, and sequential. Along with Zimmerman, these methods and approaches offered strategy options to Christian schools wishing to meet the needs of children with disabilities.

\section{The rise of homeschooling among conservative Christian parents.}

Homeschooling is a relatively new educational phenomenon, as a national movement. Data regarding this phenomenon in Christian circles is beginning to be made available, but is relatively difficult to locate. Conservative Christian parents, like conservative Christian school administrators, often are hesitant to disclose information, fearing the potential the future intrusion via governmental mandates. While an exact number of children being homeschooled is virtually impossible to know, Lines (1998) estimated that over one million are homeschooled in the United States.

Conservative Christian parents have several motivations for homeschooling their children (Jones, 2008). Some Christian parents believe that God has appointed parents with the responsibility to educate their own children. There are others who are not able to afford tuition to a private school but still want to give their children a Christian education. Other Christian parents desire to be free of the bonds of the government and see homeschooling as a way to exercise their freedom to choose how their children are educated. Other views undoubtedly exist regarding homeschooling motivations by parents, but the most salient, over-riding motivator among conservative Christian parents is to fulfill the best interests of parents' children (Longbottom, 2005). 


\section{A Historical Analysis of Special Education}

While parents who homeschool pay taxes that help fund local public schools, these same parents are eliminating the contribution of potential federal funds from the respective area schools by choosing not to enroll their children in these schools.

Similarly, conservative Christian schools, also feel the effects of homeschooling when parents choose to remove their children from conservative Christian schools. Though not directly affecting policy decisions of Christian school boards, homeschooling affects the culture of the special education in conservative Christian schools. With fewer students attending conservative Christian schools, the task of developing special education services becomes more daunting. Fewer students means less tuition is paid to support conservative Christian schools. Reduced funds from tuition forces conservative Christian schools to focus, not on what will attract new students needing special education services, but what will keep the type of students at their school (Sikkink, 2001). If there are few children with special needs in a given conservative Christian school, the need for special education services may be seen as negligible, thus removing the motivation to develop potentially helpful special education programs.

Even with the rise of homeschooling, some people still believed that conservative Christian schools should offer special education services to students with academic and developmental needs. For example, River City Christian School (RCCS) opened in 1994 in the home of Stuart and Rosemary Craig, members of River City Fellowship (River City Christian School, 2010). RCCS has grown from 8 students in 1994, to more than 140 students in 2005 . Accredited by the International Christian Accrediting Association (ICAA), RCCS is a member of ORUEF. Children from kindergarten 


\section{A Historical Analysis of Special Education}

to 12 th grade, with learning and emotional disabilities, receive educational services at RCCS. RCCS is located in San Antonio, Texas.

Another example is Achievers' Center for Education (ACE). ACE began in 2003 by parents with a desire to begin a school that would meet the needs of middle school children with disabilities. As an educational option for 6th through 12th graders who are two or more years behind grade level in any academic area, ACE enrolls students with developmental and learning disabilities. ACE, a member of ORUEF, is located in San Antonia, Texas and enrolls up to 29 students each year.

Along with Elim, Shepherds, LLH, HTCS, GSLC, and Master's Academy, RCCS and ACE also have sought to meet the needs of children with disabilities. With small student to teacher ratios (at most a 10:1 ratio), these eight conservative Christian special education schools represent a rare occurrence among conservative Christian schools. While providing services to children with disabilities, they continue to separate children with disabilities from their nondisabled peers. Although not ideal, the lack of special education programs in conservative Christian schools seemingly have compelled parents to support these schools as the only viable alternatives, being schools that are willing to give a Christian education to children with disabilities.

\section{Conclusions}

The four turning points in the historical development of present-day special education in conservative Christian schools continue to influence the special education debate. The return of WWII veterans with disabilities began a change in the cultural response to adults and children with disabilities. Families of veterans with disabilities 


\section{A Historical Analysis of Special Education}

did not want to see institutions for the disabled become the living quarters of veterans with disabilities. As families began to evaluate the needs of those with disabilities, another movement was taking place. The Civil Rights Movement of the 1950s challenged the racial equality of public schools in the United States. It was this changing perspective of equality that ultimately contributed to the Supreme Court decision in Brown to ensure that education was available to all children. IDEA, which directly references Brown, was arguably the most important historical event studied, because the mandate reflected a change in the view of children with disabilities and how those children should be educated. Additionally, the options available to conservative Christian schools regarding special education services were developed during this era. Although special education in conservative Christian schools was not firmly established, the policies and viewpoints of the time continued for many years to follow.

The development of special education teaching methods by Orton (1925) and Zimmerman (1972) contributed to the development of special education in conservative Christian schools. Orton and Zimmerman offered a practical approach to special education services. Orton's teaching methods provided the basis for several teaching methods that have been used in conservative Christian schools (Friesen, 2002). Zimmerman's approach to special education, involving a therapist, paid for by the parents, was considered tuition-conscious. Theoretically, the basic tuition of a conservative Christian school did not need to increase, since parents of children with disabilities were the sole funders of the educational therapists. 


\section{A Historical Analysis of Special Education}

Eight conservative Christian schools have been established with the intent of giving a Christian education to children with disabilities (see table 1.1). Most of these schools were started by parents of children with disabilities who desired a Christian education for both their own children and other children with disabilities (Achievers' Center for Education, 2010; Elim Christian Services, 2010; Hidden Treasure Christian School, 2010; Little Light House, 2010; Master's Academy, 2010; Shepherds Ministries, 2010). Parents often have been the voice behind special education services, both in public and private communities, leading to recognition of what children with disabilities can offer to communities.

Finally, the homeschooling movement has once again brought funding to the forefront of the debate for special education services in conservative Christian schools. While most Christians would not deny that children with disabilities should not be excluded from Christian schools (Ooserhuis, 1998), children with disabilities are regularly excluded on the basis of funding. Funding offers the most cogent barrier to special education programs in conservative Christian schools. Balancing a quality education with an affordable tuition is a challenge for every conservative Christian school (Eigenbrood, 2004). As a result of this juggling act, conservative Christian schools are hard pressed to justify, in dollars, the need for special education (Sutton et al., 1993). Although public funds are available, there are many reasons why conservative Christian schools may not participate in these funds, including the following: 1) Christian school administrators and school boards are wary of governmental involvement and influence, 2) Conservative Christian school administrators have not raised capital in 
A Historical Analysis of Special Education

order to fund special education, and 3) Conservative Christian school administrators and school boards may be unaware of the funding available. 
Table 1.1 Christian Special Education Schools in the United States

\begin{tabular}{|c|c|c|c|c|c|c|}
\hline School & $\begin{array}{c}\text { Affiliated } \\
\text { organization }\end{array}$ & $\begin{array}{l}\text { Date } \\
\text { Founded }\end{array}$ & $\begin{array}{l}\text { Grade } \\
\text { Level }\end{array}$ & $\begin{array}{l}\text { Current } \\
\text { enroll- } \\
\text { ment }\end{array}$ & $\begin{array}{l}\text { Disabilities } \\
\text { served }\end{array}$ & Location \\
\hline $\begin{array}{l}\text { Elim } \\
\text { Christian } \\
\text { Services }\end{array}$ & $\begin{array}{c}\text { Christian } \\
\text { Schools } \\
\text { International }\end{array}$ & 1948 & $\begin{array}{l}\text { Age 3-21, } \\
\text { adults }\end{array}$ & $* 800$ & $\begin{array}{c}\text { Physical and } \\
\text { developmental } \\
\text { disabilities }\end{array}$ & IL \\
\hline $\begin{array}{l}\text { Shepherds } \\
\text { Ministries }\end{array}$ & Independent & 1957 & adults & $* 300$ & $\begin{array}{l}\text { Adults with } \\
\text { physical and } \\
\text { developmental } \\
\text { disabilities }\end{array}$ & WI \\
\hline $\begin{array}{l}\text { Little Light } \\
\text { House }\end{array}$ & ORUEF & 1972 & $\begin{array}{l}\text { Preschool } \\
\text { ages } \\
\text { birth }-6\end{array}$ & $* 64$ & $\begin{array}{c}\text { Physical and } \\
\text { developmental } \\
\text { disabilities }\end{array}$ & $\begin{array}{c}\text { OK, MS, } \\
\text { TX }\end{array}$ \\
\hline $\begin{array}{l}\text { Hidden } \\
\text { Treasure } \\
\text { Christian } \\
\text { School }\end{array}$ & AACS & 1981 & $\mathrm{~K}-12$ & $* 47$ & $\begin{array}{c}\text { Physical and } \\
\text { developmental } \\
\text { disabilities }\end{array}$ & SC \\
\hline $\begin{array}{l}\text { Gateway } \\
\text { School and } \\
\text { Learning } \\
\text { Center }\end{array}$ & ACSI & 1984 & $1-12$ & $* 37$ & Dyslexia & AK \\
\hline $\begin{array}{l}\text { Master's } \\
\text { Academy }\end{array}$ & ACSI & 1988 & $4-12$ & $* 35$ & $\begin{array}{c}\text { Learning } \\
\text { disabilities }\end{array}$ & TX \\
\hline $\begin{array}{l}\text { River City } \\
\text { Christian } \\
\text { School }\end{array}$ & ORUEF & 1994 & K-12 & $* * * 140$ & $\begin{array}{l}\text { Learning and } \\
\text { emotional } \\
\text { disabilities }\end{array}$ & TX \\
\hline $\begin{array}{l}\text { Achiever's } \\
\text { Center for } \\
\text { Education }\end{array}$ & ORUEF & 2003 & $6-12$ & $* * 29$ & $\begin{array}{l}\text { Learning and } \\
\text { developmental } \\
\text { disabilities }\end{array}$ & TX \\
\hline
\end{tabular}

*Student to teacher ratios of 8:1 (even less if students need individual aides)

**Student to teacher ratio of $4: 1$

$* * *$ Student to teacher ratio of 10:1 


\section{A Historical AnAlysis Of SPECial EduCATION}

\section{DISCUSSION AND IMPLICATIONS}

The present study was conducted in order to analyze the major turning points in the development of special education in conservative Christian schools since 1950. Care was taken to identify the extent to which specific events prompted the development or hindrance to the development of special education programs. The impact on contemporary special education programs, zeitgeist influences, and important political implications, and their impact on contemporary special education in conservative Christian schools were explored.

\section{Historical Summary}

With the return of veterans with disabilities after World War II, and the desire of families to avoid institutional life for those veterans, the cultural perspective of disabilities began to change. As educators began to make the connection between adults with disabilities and children with disabilities, parents no longer wanted to place children in understaffed and poorly funded institutions. The rise of civil rights legislation that mandated the immediate demise of racial segregation, also created an awareness of the exclusion of persons based on disability in addition to other social factors; this shift in thinking lead to legislation to eliminate discrimination against persons with disability. After the passing of the Supreme Court decision in Brown v. Board of Education, parents and educators continued to pursue equal educational opportunities for all children.

In 1962 and 1963 the Supreme Court removed prayer and Bible reading from public schools. The desire to put a distance between church and state drove a number 


\section{A Historical Analysis of Special Education}

of conservative Christian parents from the public schools. While conservative Christian schools focused on the challenges of funding and separating themselves from government influence, the passing of P.L. 94-142 in 1975 marked significant change in public schools. Every public school was required by law to provide special education services to children with disabilities and government funding would also be available to all public schools in order to ensure the offering of special education services. While conservative Christians continued to develop schools in response to the changes in the 1960s, public schools were wrestling with the "how to" of special education programs.

Some conservative Christian schools, however, offered special education services. There have been at least 8 conservative Christian schools started in the last 60 years devoted to meeting the needs of children with disabilities. These schools are located around the country and are associated with different Christian school organizations. They all have a focus on offering a Christian education exclusively to children with disabilities who are not otherwise served in traditional Christian schools. Six out of 8 schools have student to teacher ratios of 8 to 1 , with some being as low as 1 to 1 when aides are taken into account. These schools ensure that their teachers are certified in special education methods, typically meaning they are certified by a state affiliated program or by experts in a specific special education strategy (i.e. OrtonGillingham Method, Hermon Approach, etc.). Parents were the primary drive behind the establishment of seven out of eight of these schools and continue to be the strongest advocates for special education programs. 


\section{A Historical AnAlysis Of SPECial EduCATION}

\section{Biblical Integrative Component \& Implications}

From the historical survey, it has become clear that federal legislation and American citizens have been wrestling with issues of equity to formerly or historically marginalized groups. Related to that issue is equality in education and the funding of education for students with disabilities. As responsible citizens and Christians, who value a biblical emphasis in children's education, it becomes necessary to evaluate biblical mandates and principles that address 1 ) a responsibility to meet the educational needs of all children who are required to attend school and who may select to attend in a Christian environment, and 2) the issue of funding which relates to favoritism based on economic status as addressed by the Bible.

Parents have been a key part of the start of special education programs in conservative Christian schools (Eigenbrood, 2004). This aligns with the biblical principle of Deuteronomy 6 where parents are challenged to pass on to their children what they have learned about the Bible's centrality to the Christian life. Deuteronomy 6 challenges parents to instill in the next generation a fear of the Lord and a reminder of His promises. In Ephesians 6:4, parents are challenged to bring their children up in the nurture and admonition of the Lord. The Bible does not directly refer to "school" in any sense. In our current cultural milieu, children are required by law to attend school from ages 7 to 18 and, consequently, Christian parents must consider how school and school environments may align with the Biblical mandate. As parents pursue Christian education, they must also recognize that they have the ultimate responsibility for educating their children in the statutes of the Lord. 


\section{A Historical Analysis of Special Education}

While education is a modern, western invention and not spoken of directly in the Bible, there are portions of Scripture regarding how Christians within Christian communities should view and care for others. This includes those with disabilities. First, the conservative Christian community must acknowledge that children with disabilities are created in the image of God (Gen. 1:26). Children with disabilities have been fearfully and wonderfully made and are precious in the sight of God (Psalm 139:13-18). Though Christians are quick to claim this truth, actions to address the needs of children who take more time, resources, and caring should reflect the commitment. Next, each believing child with a disability has gifts and abilities that have been given to them by God (Romans 12:6). While these gifts and abilities may look different from those of a child without disabilities, these children have been created for a specific purpose (Ephesians 2:10). Not every child experiences spiritual growth in a traditional school setting. However, every child (including those with disabilities) should be an integral part of the conservative Christian community. Jesus Christ was the ultimate example of accepting the marginalized and weak. Christ ministered to sinners and tax collectors, who were seen as outside of the Jewish community of the day (Luke 15:1-2). He accepted those who were sick and disabled, healing and forgiving their sins (Matthew 14:34-36; Matthew 15:21-28; Mark 7:32-35; Mark 10:46-52; Luke 5:12-14;

Luke 6:6-10; Luke 7:11-17; Luke 18:35-43; John 4:46-53; John 5:1-15; John 9:1-11).

Christ challenged his disciples and those who followed Him to love others as they love themselves (Luke 10:25-37). While Christ's ministry on earth does not directly relate to a traditional school setting, it does relate directly to the focus of a Christian 


\section{A Historical Analysis of Special Education}

community. Every Christian community should be showing love for all within and outside of that community (Luke 10:37). This does not mean that every person will be treated identically, as Christ illustrated that each person should be looked at as an individual with individual needs to be addressed.

\section{Discussion}

Ways Relevant Paradigms Affect the Study

Two modern special education paradigms exist in conservative Christian schools (Eigenbrood, 2004). The goals, methods, and philosophies behind the two approaches differ. An understanding of these two paradigms helps to explain the different approaches to special education.

One approach to special education in conservative Christian schools views special education as a Biblical mandate, and, as such, a priority for funding (Vincent, 2006). As a result, the fiscal budget is developed with an intentional focus on ensuring funding for special education services to children with disabilities. Funding is not seen as an obstacle to prevent special education services but, rather, an obstacle to overcome in order to ensure those services are made available.

A second approach views special education as an addition to the school budget (Eigenbrood \& Eigenbrood, 1994). As a result of this view, the fiscal budget is developed with special education viewed as an elective. Formal special education programs often are not offered in conservative Christian schools with this view, because funding is not available for ancillary services such as special education. 


\section{A Historical Analysis of Special Education}

Each approach begins with a different premise for funding special education programs. There are conservative Christian schools which are not able to fund special education programs but still accept students with disabilities. These administrators work with parents in order to ensure that various modifications and adaptations are implemented where practical and feasible. Ultimately, however, parents must take responsibility for ensuring that their child with disabilities is given an appropriate education.

A review of history since 1950 reveals that the dominant cultural message of the 1950s relating to children with disabilities strongly emphasized hiding those children from society (Winzer, 2002). During that same time, however, counter cultural groups, individuals, and philosophies began to promote the education of children with disabilities in order to encourage interaction with society. They stressed that education was a basic human right and that all children had a right to an appropriate education. Christian writers challenged the conservative Christian community through articles (King, 1978; Pierson, 1975; Pierson, 1978) and books (Bogardus, 1963; Ebersole, 1964; Grammer, 1981; Groff, 1986; Hawley, 1981; Kemp, 1957; Malone, 1986; Palmer, 1961; Rogers, 1953) to accept the Biblical mandate for special education, namely caring for the Christian community. Throughout the latter half of the $20^{\text {th }}$ century the view of equal educational opportunities for all children was gradually accepted by more Americans.

During the 1960s, Christian parents became increasingly disillusioned by what they saw as a neglect of their beliefs in the public schools. It was in retaliation to this 


\section{A Historical Analysis of Special Education}

neglect that many parents withdrew their children from public schools and placed them in conservative Christian schools. As a result, Christian schools distanced themselves from contemporary laws that were bringing about the secularization of public schools, including P.L. 94-142. It is understandable, then, that conservative Christian schools in the 1960s did not consider students with disabilities as a part of the student body to address. Children with disabilities were being housed in institutions, away from society, as was considered to be in the children's best interest. As a result of this, the Biblical mandate for special education is directly related to the two relevant paradigms. As some Christians embraced the belief that there was a Biblical mandate to address the needs of students with disabilities, churches and schools decided to adapt programs to meet the varied needs of students. Christians who did not see special education as part of a biblical mandate frequently used funding as a reason for not providing school services to students with disabilities. With limited funding available for special education programs in public schools and no funding available for private schools, in addition to the desire to avoid governmental control, Christian schools felt no obligation to offer special education programs (Oosterhuis, 1998). I will address each of these paradigms along with suggestions for future action in light of historical examples of successful conservative Christian school programs in addition to a synthesis of collected historical data.

\section{The Funding Dilemma}

The data indicated that funding offers the greatest barrier to special education programs in conservative Christian schools. Balancing a quality education with an 


\section{A Historical Analysis of Special Education}

affordable tuition is a challenge for every Christian school (Eigenbrood, 2004). As a result of this juggling act, conservative Christian schools are hard pressed to justify, in dollars, the need for special education (Sutton, Sutton, \& Everett, 1993). Although public funds are available, there may be many reasons why conservative Christian schools may not participate in these funds, including the following: 1) conservative Christian school administrators and school boards are wary of govern mental funding, 2) conservative Christian school administrators have not raised capital in order to fund special education, and 3) conservative Christian school administrators and school boards may be unaware of the funding available.

Conservative Christian school administrators and school boards are exceptionally wary of governmental funding and the strings typically attached (Reese, 2004).

Christenson et al. (2007) surveyed private, religious schools and found that $32 \%$ in their sample consciously refused governmental funding. One reason for this conscious refusal in conservative Christian schools is the desire of administrators and schools boards to remain separate from the secular world (Marsden, 2006). In order to receive funding from the government some conservative Christian schools believe that unacceptable compromises would be made.

Historically, conservative Christian school administrators have not been widely engaged in the practice of raising capital, including endowments, as part of their funding practices. Most conservative Christian school administrators and school board members depend on student tuition in order to fulfill the needs of the annual budget (Sikkink, 2001). When there is a lack of money (i.e., when student enrollment goes 


\section{A Historical Analysis of Special Education}

down), programs for students must be reduced. Because special education services have not been considered as high priorities, they are treated as optional services, based upon adequate finances. Without long-term, sustained funding, the future of offering special education services in conservative Christian schools is bleak at best (Sutton, 1992).

Finally, conservative Christian school administrators and school board members may be unaware of the funding available. There has been considerable debate regarding the relationship of IDEA to private, faith-based schools (Drang \& McLaughlin, 2008; Latham, 2000). One result of this debate is a lack of understanding on the part of conservative Christian school administrators regarding what services are available to their students (Eigenbrood, 2004). In order for administrators and board members to evaluate opportunities to serve students with disabilities in their area, it is necessary for them to be informed about what services may be available to their schools at no cost (Osborne, Russo, \& DiMattia, 1999). Public schools are not required to use their own funds, but rather a proportionate amount of government funds that have been given for special education services (Latham, Latham, \& Mandlawatz, 2008). In order for services to be appropriately offered, the child (and not the school) must be the primary beneficiary. The services must be provided in a neutral manner, inferring that Christian schools receive no direct benefit from the funds provided, and to a broad class of citizens without reference to religion, implying that children from different religious backgrounds could be offered services together. For the conservative Christian school, this purports that when services are determined the public school and Christian school 


\section{A Historical Analysis of Special Education}

personnel must determine which services could be offered to the greatest number of children (such as offering speech therapy or language arts tutoring to a group of students) and where those services would be offered.

In addition to working with the public school to offer services, Christian school administrators and educators could work with public school personnel to creatively collaborate in providing educational services for students with disabilities. Furthermore, Christian school teachers may be able to receive additional training and professional development that would allow them to serve certain students with disabilities within the existing contexts and classrooms. Public funds cannot be used to train Christian school teachers, but public school personnel may be willing to work with private school teachers to provide these services.

Conservative Christian schools typically rely heavily upon tuition to meet their budget needs. This business model, however, has proven ineffective in allowing conservative Christian schools to offer what parents of students with disabilities desire in terms of special education. Similar to a personal budget, money is earmarked for those items that are a priority and, items that are not a priority, receive whatever funds that are left over. Likewise, when running a budget for a school, administrators and school boards must determine what the priority of the tuition funds will be. Alternative sources of funding for special education services may need to be considered, including targeted fundraising. How they go about that fundraising may be different for each group, but it is an option that should be explored. Successful models of conservative Christian schools that have been able to offer special education services should be 


\section{A Historical Analysis of Special Education}

considered (e.g., Little Light House and River City Christian School). Conservative

Christian schools should collaborate in order to discuss how these fundraising strategies could help provide for the needs of more children with disabilities. Networking among conservative Christian schools is of utmost importance in this regard. National organizations could utilize their networks to serve as a collaborative agency for effective models, and use their networks to encourage and support schools who desire to support students with disabilities. This would encourage the teamwork and collaboration necessary to develop creative ways to meet the needs of students with disabilities.

In summary, the data indicates that a majority of conservative Christian schools do not offer special education services to children with disabilities on the basis of a lack of funding. For some of these schools, a misunderstanding exists regarding what special education services involve (AACS, ACSI, and ORUEF member schools' secretaries and principals, personal communications, May 30, 2010). For other schools, special education is viewed as an elective to the budget and not a priority (Sutton, Sutton, \& Everett, 1993). In view of this dilemma, a series of suggestions to address this issue will be presented.

\section{Options Available to Conservative Christian Schools}

Conservative Christian schools that offer special education services to children with disabilities do so through a number of different strategies. From the data presented, several models have been implemented historically, including schools that have been established to teach students with disabilities exclusively. Some of the these 


\section{A Historical Analysis of Special Education}

schools survive solely on tuition revenues, while others are able to offer services as a result of contributions and donations given by individuals and church communities. I contacted several conservative Christian schools, specifically those who do not work exclusively with students with special needs, which choose to make special education a priority of the budget through a variety of means: (1) hiring an NILD therapist for whom parents are responsible to pay, (2) working with the public school to offer services (specifically speech and tutoring services), and (3) including special education as a part of the tuition cost to all parents. However, other options exist to address the educational needs of students with disabilities.

Conservative Christian schools have the local public school at their disposal. The reauthorizations of IDEA allocated funds to private schools in order to help establish special education services. As has already been stated, students are not entitled to the same services as their regular education peers, but they are entitled to some of services. This means that students can receive speech, occupational, and physical therapy, or even tutoring services, at no cost to the Christian school or to parents. Parents, teachers, and administrators at the conservative Christian school should consider working closely with public school officials in order to determine which services potentially could be most appropriate and might serve the greatest number of students. Location would also need to be discussed, since most public schools are not comfortable offering services on site at a conservative Christian school but are willing, instead, to transport students to a more neutral location for those services. 


\section{A Historical Analysis of Special Education}

Another option available to conservative Christian schools involves cooperating with other local conservative Christian schools. Conservative Christian schools could form co-ops, circulating teachers, school psychologists, as well as other resources to help make services more affordable to respective schools. In this way, conservative Christian schools could acquire special education services at a more reasonable rate dividing the salaries of appropriate service personnel between participating schools. This model also would allow schools the expertise of qualified professionals who would have the experience and background to train current conservative Christian school teachers and administrators in current special education practices. Within the same state, conservative Christian schools would have the opportunity to network and coordinate services together. This would be a more cost-effective way to meet the needs of their student population with disabilities. Certified special education teachers and therapists could, theoretically, be shared between several schools. In this way these certified specialists would be able to offer services to children with disabilities at several sites and the conservative Christian schools would have the opportunity to split the cost of said specialist salaries.

An additional option available involves the cooperation and collaboration of Christian universities and national organizations. These universities and organizations could coordinate an extensive effort to enhance awareness of free, no-strings-attached, (district) public school resources available to local conservative Christian schools. While few researchers have examined how a working public-private school relationship should operate (Drang \& McLaughlin, 2008, Eigenbrood, 2004, Osborne, Russo, \& DiMattia, 


\section{A Historical Analysis of Special Education}

1999, Russo, Osborne, Massucci, \& Cattaro, 2009), there is information available to conservative Christian schools regarding the nature of IDEA and the funds available. In addition to funds available for direct services to students with disabilities, organizations could serve as a clearinghouse for information related to professional development for teachers that possibly will enhance their ability to meet the needs of a greater number of students with disabilities within existing classrooms. By being familiar with IDEA and the relating funds, appropriate training may possibly be given to administrators, teachers, and educators regarding what is available to them through IDEA. This training might be offered at Christian universities or through national Christian school organizations (i.e., AACS, ORUEF, etc.). While there are some organizations that offer seminars on special education, these organizations may perhaps expand their work by connecting and encouraging Christian schools within their organization to offer special education services.

A final option available to conservative Christian schools involves training administrators and teachers in current special education techniques. Palmer (1961) and Eigenbrood (1994) both challenge conservative Christian schools not to be distracted by the labels students receive. While knowledge of specific disabilities can aid teachers in providing appropriate instruction to students with disabilities, modifying curriculum should not be based entirely on the special education categorization. Teachers at conservative Christian schools must look beyond the disability and see each child individually. Special education is meant to be individualized instruction - the bottom line is the need for a clear definition of special education. The separation and reduced 


\section{A Historical Analysis of Special Education}

opportunities for students with disabilities may need to be reconsidered if Christian educators develop a paradigm where they accept the challenge to meet the unique learning needs of every student (Tucker, 1993). While public schools are bound by the mandates of the government, conservative Christian schools are not and have the opportunity to provide special education services to students beyond the scope of the categorization used in public schools. Teachers in conservative Christian schools have the opportunity think creatively, giving action to their convictions that each child is a unique creation of God. Already, many teachers are differentiating instruction to meet the needs of their students. This is a form of special education that is already being implemented. I suggest that it is important to recognize how many Christian teachers are already modifying and adapting curriculum to responsively meet student needs. I contend that, in reality, special education in the form of individualized instruction is occurring, but it is not labeled as "special education."

Special education, by definition, is specifically designed instruction (Tucker, 1993). While there is little data available regarding the current status of special education in conservative Christian schools, my research uncovered many misunderstandings regarding special education. In personal communication with more than 150 schools, approximately 25 stated that special education was directly related to a specific label (e.g., Down Syndrome, ADHD, MH) and not to the student. Two school administrators indicated that they would not consider services offered to students with ADHD as special education services. In conversations with four school officials working only with children with behavior issues, administrators shared that they did not believe 


\section{A Historical Analysis of Special Education}

they offered any special education services to students, even though their schools were very small, in order to offer an individualized learning environment to each student.

Data indicates that school personnel define special education in varying ways, and make a distinction between services offered to students with varying types of disabilities. McCormick (1999) found that principal perceptions toward special education substantially affected the services offered to students with disabilities. For example, a broader information base regarding disabilities helped motivate administrators in establishing quality programs to service children with disabilities. Lack of expertise and information about special education appears to be a significant hurdle in addressing the needs of students with disabilities. As a result of high turnovers among teachers (Ingersoll, 2005; Nevin \& Bills, 1976), conservative Christian schools often struggle with consistency among their teachers, regular and special education. A lack of consistency in any area of education generally disrupts the development of services to children. As a result, conservative Christian schools frequently do not have the consistency needed to foster quality services to students with disabilities.

\section{The Special Education Continuum}

In interpreting the data and offering alternatives, I acknowledge that the cost of educating a child with disabilities is twice as much as that of a child without disabilities (Chambers, Parrish, \& Harr, 2004). Financial realities create and limit possibilities for administrators who seek to be financially accountable. There are those students whose needs are beyond the scope of what a public school can offer, as well as a conservative Christian school. For example, a child with severe physical disabilities may need the 


\section{A Historical Analysis of Special Education}

extensive care offered at a private, special education facility (such as Elim Christian School or Hidden Treasures Christian School). Parents and educators must evaluate where each child can be most effectively serviced. For many of these students, interacting within the Christian school on a part time basis may be a possible way for students to be engaged within the Christian community, but also have their educational needs met. For other students, a modified school day with very specific instruction, possibly at a boarding school, would lead to more educational success. Historical data related to special education and conservative Christian schools has indicated that, up to the present, Christian schools have considered limited options as possibilities for including students with disabilities and meeting their educational needs. I suggest that more students with disabilities may be effectively served in conservative Christian schools if parents and school personnel are more knowledgeably informed about funding options. In addition, possibilities exist for conservative Christian school personnel to redefine their parameters for inclusion and exclusion of students into existing classrooms and for them to creatively work and collaborate to meet the needs of students with disabilities without adversely impacting services offered to other students.

\section{Conclusions}

The present study provides potentially significant, relevant application for parents and educators. They can gain a clearer insight into how special education has developed in conservative Christian schools in order to better understand how to advocate for the education of children with disabilities. Conservative Christian school 


\section{A Historical Analysis of Special Education}

board members and administrators can benefit from this assessment as they make decisions regarding whether or not they should allocate funding for special education services. Networking is of utmost importance since school budgets are assessed in light of providing special education to children with disabilities. School board members and administrators also have the opportunity to network with schools that only provide special education services in order to develop an action plan for meeting needs.

Christian school organizations seeking to improve networking among schools can make more informed decisions by gaining a clearer understanding of special education and how funding can be made available. In doing so, each of these stakeholder groups can make specific use of the analysis in this study.

The first application explores one reason that understanding historical events of special education in conservative Christian schools in America is important. The past is the root of the present and a potential prediction for the future (Huber, 2009). An analysis of history in the development of special education and conservative Christian schools over the years assists the understanding of recurring problems in an effort to correct them. For example, it is important that educators seeking to implement special education programs in conservative Christian schools understand why administrators and school board members have not previously funding special education programming. It prompts curriculum developers to discover potential alternative ways to fund special education programs in order to encourage the development of those programs.

Second, this study encourages a closer look at funding options available to conservative Christian schools. While a majority of conservative Christian schools do 


\section{A Historical Analysis of Special Education}

not offer special education services, those that do offer them are able to do so using a variety of methods (e.g., Orton-Gillingham Approach, Hermon Method, NILD therapists, etc.). The present study brings to light a brief overview of these methods and can serve as a springboard for furthering the exploration of additional alternative paradigms that may be effectively implemented or integrated into existing Christian school curricula.

Finally, this study brings to light the lack of networking among schools within conservative Christian school organizations. Within the same state, conservative Christian schools are unaware of what others are doing to meet the needs of children with disabilities. Ultimately, the conservative Christian school organizations exercise influence regarding the level of networking that happens between schools. If more information were available through these organizations regarding the development and funding of special education programs, then perhaps more conservative Christian schools would see special education as a priority, instead of an elective considered in the budget.

\section{Strengths of the Study}

This study is the first formal and intentional documentation of the key historical events that assisted the development or hindrance of special education services in conservative Christian schools. Previous studies were focused on either the formation of conservative Christian schools or on locating conservative Christian schools that offer special education services. The few studies that explored the history of special education in conservative Christian schools did so within the context of sharing strategies that conservative Christian schools can use. They did not explore the 


\section{A Historical Analysis of Special Education}

development of special education in conservative Christian schools or investigate why programs either did or did not form, nor did they draw comparisons to historical events with the present day features of special education in conservative Christian schools.

This study also encourages cultural engagement among Christians regarding special education. This analysis of the history of special education in conservative Christian schools, together with its implications, provides the record of the lack of information available regarding special education programs in conservative Christian schools. Christians are challenged to biblically reflect on current philosophical positions and to prioritize the initiation of novel funding endeavors to provide their children with a formal Christian education in a traditional Christian school milieu.

\section{Limitations of the Study}

From its inceptions, I have chosen specific limitations to my document study in order to keep the information at a manageable level. The first is that I chose to define conservative Christian schools as schools affiliated with one of four Christian school organizations. There are several other "Christian" organizations that support privatereligious schools in the United States. These organizations were not addressed. A second limitation came as a result of the type of study performed. A historical analysis is not a quantitative one that involved statistical analysis. Rather, a historical analysis appraises the progression of events and paradigms.

A third limitation of this study is that it provided only a brief overview of the homeschooling movement. Examining the homeschooling movement among conservative Christian parents would provide some key insights into the special 


\section{A Historical Analysis of Special Education}

education movement. The homeschooling movement has likely affected the development of special education programs in conservative Christian schools through parents of children with disabilities choosing to educate their children at home instead of at a conservative Christian school. Future researchers should examine this phenomenon more fully in order to understand its complete affect on conservative Christian schools and its relations to special education.

Fourth, this study did not examine individual programs at conservative Christian schools. Other studies have been conducted, sharing strategies that conservative Christian schools potentially can use to implement special education programs (e.g., Ramirez \& Stymeist, 2010; Stymeist, 2008). An in-depth examination of the special education programs offered by conservative Christian schools may contribute to a clearer understanding of what conservative Christian schools are currently doing in terms of meeting the needs of students with special needs.

Finally, a third limitation of this study is the minimal information that was able to be collected from target schools. While I left messages and asked many questions of secretaries, I was unable to acquire the desired breadth or depth in the information about these schools. Acquiring more information from the 8 conservative Christian special education schools may have provided a more exhaustive list of funding options available to conservative Christian schools.

\section{Suggestions for Future Research}

This study provided an important beginning to the understanding of key influences in the development of special education in conservative Christian schools in 


\section{A Historical Analysis of Special Education}

America, but further study would add depth and richness to an understanding of this topic. Additional research is needed on the philosophies that are held by Christian school personnel related to students with disabilities and educational services to meet their needs. Moreover, in depth contact would provide a more rich set of data. Based on my personal contact with over 100 schools, more than half of the school personnel with whom I spoke seemed unsure of what can be labeled "special education services" within a school setting. Further study to determine a working description of special education would enable a researcher to better examine how many conservative Christian schools are actually offering special education services.

Another suggestion for further research is to examine each of the member schools of the organizations included in this study. Contacting every school, or even visiting and documenting their actual interactions with students with disabilities, would provide a clearer picture of what is currently happening in conservative Christian schools. Also, examining how conservative Christian school organizations are networking schools together in order to aid in the development of special education programs is an area for further research. Conservative Christian school organizations seem to have a lack of networking regarding special education programs. Further exploration may help broaden the information available to Christian school organizations in order to extend the influence of special education services to a wider population of Christian students. Additional research should also include in-depth, qualitative research studies as well as survey research regarding the 8 special education conservative Christian schools mentioned in this thesis. 


\section{A Historical Analysis of Special Education}

Further examination of how conservative Christian schools that offer special education services fund those services also warrants further research. This study found a limited number of strategies used by some schools with varying degrees of success. More in-depth study of conservative Christian schools that offer special education could potentially provide parents, educators, and administrators with key information that might help them locate currently available and yet untapped resources for helping Christian parents to fund the inevitable extra costs involved. Christian school administrators might hold seminars or workshops to help parents better understand their sacrificial, Biblical obligations towards their children, specifically noting the prioritization of Christian education and devoting the needed funds to ensure the best Christian education available to their children. 


\section{A Historical analysis of Special Education}

\section{References}

A Beka (2010). Our foundation. Retrieved May 15, 2010 from

http://www.abeka.com/OurFoundation.html

ACE. (2009). About us. Retrieved December 14, 2009 from

http://www.schooloftomorrow.com/aboutus/Default.aspx

AACS. (2009). History. Retrieved October 10, 2009 from http://www.aacs.org/history/

ACSI. (2009). History. Retrieved October 10, 2009 from

http://www.acsi.org/tabid/535/itemid/76/default.aspx

ACSI. (2010). Directory. Retrieved April 15, 2010 from

http://www.acsi.org/FooterLinks/MemberDirectory/tabid/577/Default.aspx

Agostini v. Felton, 521 U.S. 203 (1997).

Ammerman, N. T. (1991). North American protestant fundamentalism. In M. E. Marty, \& R. S. Appleby (Eds.) Fundamentalisms observed (pp. 1-65). Chicago: University of Chicago Press.

Anderson, J. D., Bernard, S. C., Cuban, L., Kaestle, C. F., Mondale, S., Ravitch, D., \& Tyack, D. (2001a). Why don't you go to school with us? In S. Mondale, \& S. B. Patton (Eds.), School: The story of American public education (pp. 123-170). Boston: Beacon Press.

Blatt, B., \& Kaplan, F. (1966). Christmas in purgatory: A photographic essay on mental retardation. Boston: Allyn \& Bacon.

Bob Jones University Press (2010a). About us. Retrieved June 21, 2010 from http://www.bjupress.com/about/ 


\section{A Historical Analysis of Special Education}

Bob Jones University Press (2010b). Special education at home. Retreived May 10, 2010 from http://www.bjupress.com/resources/homeschool/special-needs/

Bogardus, L. (1963) Christian education for retarded children and youth. Nashville, TN: Abingdon Press.

Braddock, D. (1987). Federal policy toward mental retardation and developmental disabilities. Baltimore: Brooks.

Broughman, S. P., Gerald, E., Bynum, L. T., \& Stoner, K. (1994). Private school universe survey, 1991-1992 (NCES 94-350). Washington, D.C.: National Center for Education Statistics, U.S. Department of Education.

Broughman, S.P., Swaim, N.L., \& Keaton, P.W. (2008). Characteristics of private schools in the United States: Results From the 2005-2006 private school universe survey (NCES 2008-315). Washington, DC.: National Center for Education Statistics, Institute of Education Sciences, U.S. Department of Education.

Broughman, S. P., Swaim, N. L., \& Keaton, P. W. (2009). Characteristics of private schools in the United States: Results from the 2007-08 private school universe survey (NCES 2009-313). Washington, D.C.: National Center for Education Statistics, Institute of Education Sciences, U.S. Department of Education.

Brown v. Board of Education, Topeka, 347 U.S. 483 (1954).

Buck, P. S. (1950). The child who never grew. New York: The John Day Company.

Carper, J. C. (1984). The Christian day school. In J. C. Carper \& T. C. Hunt (Eds.), Religious schooling in America (pp. 110-129). Birmingham, AL: Religious Education Press. 


\section{A Historical Analysis of Special Education}

Carper, J. C. \& Hunt, T. C. (2007). The Dissenting Tradition in American Education. New York: Peter Lang Publishing.

Carper, J. C., \& Layman, J. (2002). Independent Christian day schools: The maturing of a movement. Catholic Education: A Journal of Inquiry and Practice, 5, 502-514.

Chambers, J. G., Parrish, T. B., \& Harr, J. J. (2004). What are we spending on special education services in the United States, 1999-2000? (Contract No. ED99C00091). Retrieved from Center for Special Education Finance website: http://csef.air.org/publications/seep/national/AdvRpt1.PDF

Christenson, G. S., Cohodes, S., Fernandes, D., Klasik, D., Loss, D., \& Segeritz, M. (2007). Private school participants in programs under the No Child Left Behind Act and the Individuals with Disabilities Education Act: Private school and public school district perspectives. Washington, D.C.: Department of Education, The Urban Institute.

Cohen, L., Manion, L., \& Morrison, K. (2007). Research methods in education. New York: Routledge.

Detwiler, F. (1999). Standing on the premises of God: The Chrisitan Right's fight to redefine America's public schools. New York: New York University Press.

Drang, D., \& McLaughlin, M. J. (2008). Special education services for parentally placed private school students. Journal of Special Education Leadership, 21, 3-11.

Dollar, G. W. (1973). A history of fundamentalism in America. Greenville, SC: Bob Jones University Press. 


\section{A Historical Analysis of Special Education}

Ebersole, E. (1964). Christian education for socially handicapped children and youth. Boston: United Church Press.

Eigenbrood, R. (2004). IDEA requirement for children with disabilities in faith-based schools: Implications for practice. The Journal of Disability Policies, 15, 2-8.

Eigenbrood, R. (2005). A survey comparing special education services for students with disabilities in rural faith-based and public school settings. Remedial and Special Education, 26, 16-24.

Eigenbrood, H., \& Eigenbrood, R. (1994). Challenges and opportunities: Special education in Christian schools. Christian Educators Journal, 34, 10-11.

Elim Christian Services. (2010a). History. Retrieved May 17, 2010 from http://www.elimcs.org/index.php/about/history

Falwell, J. (1980). Listen America! New York: Doublday.

Friesen, K. (2002). Resources for meeting special needs: A summary of six programs/methods/ approaches that effectively assist students with special learning needs. Christian School Education, 4, 12-13.

Gateway School and Learning Center - Dyslexia (2010). School. Retrieved May 17, 2010 from www.gatewayschoolak.com/home/school

Giordano, G. (2007). American special education: A history of early political advocacy. New York: Peter Lang Publishing.

Grammer, L. A. (1981). Christian education and special education. In W. C. Graendorf (ed.). Introduction to Biblical Christian education (pp. 368-375). Chicago: Moody Press. 


\section{A Historical Analysis of Special Education}

Groff, R. L. (1986). Teaching intellectually impaired children. In R. E. Clark, J. Brubaker, \& R. B. Zuck (Eds.). Childhood education in the Church (pp. 183-200). Chicago: Moody Press.

Gunn, A. M. (2006). Intelligent design and fundamentalist opposition to evolution. Jefferson, NC: McFarland and Company.

Harding, S. (2009). Successful inclusion models for students with disabilities require strong site leadership: Autism and behavioral disorders create many challenges for the learning environment. The International Journal of Learning, 16, 91-103.

Hawley, G. H. (1981). How to teach the mentally retarded: There's a way to reach them. Wheaton, IL: Victor Books.

Hidden Treasure Christian School. (2010). About us. Retrieved April 14, 2010 from http://www.hiddentreasure.org/about_us.html

Hight, J. (1986). Teaching exceptional children. In R. E. Clark, J. Brubaker, \& R. B. Zuck (Eds.). Childhood education in the Church (pp. 163-182). Chicago: Moody Press. H.R. 1350--108th Congress: Individuals with Disabilities Education Improvement Act of 2004. (2003). In GovTrack.us (database of federal legislation). Retrieved June 30, 2010, from http://www.govtrack.us/congress/bill.xpd?bill=h108-1350.

Huber, V. J. (2009). A historical analysis of public school sex education in America since 1900 (Unpublished master's thesis). Cedarville University, Cedarville, $\mathrm{OH}$.

Hutchison, S. K. (2003). The fairness of accommodations for exceptional students. Christian School Education, 6, 29-30. 


\section{A Historical Analysis of Special Education}

ICAA. (2009). About us. Retrieved February 15, 2009 from

http://www.icaa.us/about.html

Ingersoll, R. M. (2001). Teacher turnover and teacher shortages: An organizational analysis. American Educational Research Journal, 38, 499-534.

Johnson, B., \& Christensen, L. (2008). Educational Research: Quantitative, qualitative, and mixed research. Thousand Oaks, CA: Sage Publications.

Jones, S. L. (2008). Religious schooling in America: Private education and public life. Westport, CT: Praeger Publishers.

Kemp, C. F. (1957). The church: The gifted and the retarded child. St. Louis, MO: The Bethany Press.

King, L. (1978). A special class for children with learning disabilities. Key to Christian Education Journal, 16(3), 10-11.

Kluth, P., Villa, R. A., \& Thousand, J. S. (2001). “Our school doesn't offer inclusion” and other legal blunders. Association for Supervision and Curriculum Development, $59,1-6$.

Kniker, C. R. (1997). Religious pluralism in the public school curriculum. In T. C. Hunt \& J. C. Carper (Eds.), Religion and schooling in contemporary America: Confronting our cultural pluralism (pp. 3-29). New York: Garland Publishing.

LaHaye, T. (1983). The battle for the public schools: Humanisms threat to our children. Old Tappan, NJ: Fleming H. Revell Company.

Latham, P. S. (2000). Non-public schools and public services under IDEA. Learning Disabilities: A Multidisciplinary Journal, 10, 21-24. 


\section{A Historical analysis of Special Education}

Latham, P. S., Latham, P. H., Manklawitz, M. R. (2008). Special Education Law (pp. 6671). Boston: Pearson Publishing.

Lines, P. (1998). Homeschoolers: Estimating numbers and growth. Washington, D.C.: U.

S. Department of Education Office of Educational Research and Improvement. Little Light House (2010). Our Story. Retrieved May 17, 2010 from $\underline{\text { www.littlelighthouse.org/ourstory.html }}$

Lockerbie, D. B. (1980). Who educates your child? A book for parents. Grand Rapids, MI: Zondervan Publishing House.

Longbottom, A. (2005). Growing at home: Nourishing your special needs child. The Home School Court Report, 21 (3), 6-9, 26-27.

Malone, A. (1986). Spreading light: Religious education for special children. Mahwah, NJ: Paulist Press.

Marsden, G. (2006). Fundamentalism and American culture. Oxford, UK: Oxford University Press.

Master's Academy (2010). Our history. Retrieved May 17,2010 from http://www.mastersacademyonline.com/history.htm

McCormick, J. J. (1993). Man's mandates for public special education. In J. P. Sutton (Ed.), Special education: A Biblical approach (pp. 83-97). Greenville, SC: Hidden Treasures Ministry.

McCormick, J. J. (1999). Effects of a professional development method in improving special education knowledge of Christian school administrators (Unpublished doctoral thesis). Bob Jones University, Greenville, SC. 


\section{A Historical analysis of Special Education}

Mertens, D. (2005). Research and evaluation in education and psychology: Integrating diversity with quantitative, qualitative, and mixed methods. Thousand Oaks, CA: Sage Publications.

NILD. (2009). About us. Retrieved October 10, 2009 from http://www.nild.net/about.asp Nevin, D., \& Bills, R. E. (1976). The schools that fear built: Segregationist academies in the South. Washington, D.C.: Acropolis Books.

No Child Left Behind Act, 20 U.S.C. pt. 6301 (2001).

Nordin, V. D., \& Turner, W. L. (1980). More than segregation academies: The growing Protestant fundamentalist schools. Phi Delta Kappan, 61, 391-394.

Oosterhuis, A. (1998). The ideology of inclusive education. Christian Educators Journal, $38,2-3$.

Oral Roberts University Educational Fellowship. (2009). Home. Retrieved December 14, 2009 from http://oruef.oru.edu/oruefmgr.oruef main.home

Osborne, A. G., \& Russo, C. J. (2006). Special education and the law: A guide for practitioners. Thousand Oaks, CA: Corwin Press.

Osborne, A. G., Russo, C. J., \& DiMattia, P. (1999). IDEA '97: Providing special education services to students voluntarily enrolled in private schools. The Journal of Special Education, 33, 224-231, 247.

Osgood, R. L. (2008). The history of special education: A struggle for equality in American public schools. Westport, CT: Praeger Publishers.

Palmer, C. E. (1961). The church and the exceptional person. Nashville, TN: Abingdon Press. 


\section{A Historical Analysis of Special Education}

Park, J. C. (1980). Preachers, politics, and public education: A review of right wing pressures against public schooling in America. Phi Delta Kappan, 61, 608-612.

Parrish, T., Harr, J., Wolman, J., Anthony, J., Merickel, A., \& Esra, P. (2004). State special education finance systems, 1999-2000: Part II: Special education revenues and expenditures. Palo Alto, CA.: The Center for Special Education Finance.

Parsons, P. F. (1987). Inside America's Christian schools. Macon, GA: Mercer University Press.

Peshkin, A. (1986). God's choice: The total world of a fundamentalist Christian school. Chicago: University of Chicago Press.

Peter v. Wedl, 155 F.3d 992 ( $8^{\text {th }}$ Cir. 1998).

Pierson, J. O. (1975). How do you teach the exceptional person about God? Key to Christian Education Journal, 14(2), 19.

Pierson, J. O. (1978). Let music help you teach. Key to Christian Education Journal, 16(3), 24-25.

Provenzo, E. F. (1990). Religious fundamentalism and American education: The battle for the public schools. Albany, NY: State University of New York Press.

Ramirez, A. Y., \& Stymeist, M. (2010). Bible theory or Biblical living: What are Christian schools providing for families with children with special needs? A Journal of the International Community of Christians in Teacher Education, 5, http://icctejournal.org/issues/v5i1/v5i1-ramirez-stymeist/ 


\section{A Historical Analysis of Special Education}

Randall, E. V. (1997). Religious schools in America. In T. C. Hunt \& J. C. Carper (Eds.), Religion and schooling in contemporary America: Confronting our cultural pluralism (pp. 83-105). New York, NY: Garland Publishing.

Ravitch, D. (1983). The troubled crusade: American education 1945-1980. New York: Basic Books.

Rawson, M. J. (2003). Special Education Law (2 ${ }^{\text {nd }}$ ed.). Naples, FL: Morgen Publishers.

Reese, W. (1985). Soldiers for Christ in the army of God: The Christian school movement in America. Educational Theory, 35, 174-194.

Reese, W. J. (2004). Changing conceptions of public and private in American educational history. In R. Aldrich (Ed.), Public or private education? Lessons from history (pp. 147-166). Portland, OR: Woburn Press.

River City Christian School. (2010). History. Retrieved April 20, 2010 from http://rivercitychristianschool.com/about/history.html

Rogers, D. E. (1953). Angel unaware. Westwood, NJ: Fleming H. Revell Company.

Rose, S. (1993). Christian fundamentalism and education in the United States. In M. E. Marty \& R. S. Appleby (Eds.), Fundamentalisms and society (pp.452-489). Chicago, IL: The University of Chicago Press.

Russo, C. J., Osborne, A. G., Massucci, J. D., \& Cattaro, G. M. (2009). The law of special education and non-public schools: Major challenges in meeting the needs of youth with disabilities. Lanham, MD: Rowman \& Littlefield Education. 


\section{A Historical analysis of Special Education}

Schimmer, J. (1996). Christian education for special children. In K. O. Gangel \& J. C. Wilhoit (Eds.), The Christian educator's handbook on family life education (pp. 189-200). Grand Rapids, MI: BakerBooks.

Shepherds Ministries (2010). History. Retrieved April 14, 2010 from http://www.shepherdsministries.org/?page=SM History

Sikkink, D. (2001). Speaking in many tongues: The common stereotypes of Christian schools may mask their healthy diversity. Education Matters, 1, 36-45.

Sikkink, D., \& Hill, J. (2006). Education. In H. R. Ebaugh (Ed.), Handbook of religion and social institutions (pp. 41-66). New York: Springer Science and Business Media.

Stymeist, M. L. (2008). Developing the heart: Private Christian schools and students with special needs (Unpublished master's thesis). Biola University, La Mirada, CA.

Sutton, J. P. (1990). Prevalence of special education programs in private Christian schools: The ACSI study (Unpublished manuscript). Bob Jones University, Greenville, SC.

Sutton, J. P. (1992). Education students with disabilities: A new item on the Christian school agenda. Journal for Christian Educators, 9(3), 7-8.

Sutton, J. P., Sutton, C. J., \& Everett, E. G. (1993). Special education in Christian/fundamentalist schools: A commitment to all the children? Journal of Research on Christian Education, 2, 65-79.

Swierenga, R. P. (2005). ELIM: A Chicago Christian school and life training center for the disabled. Grand Rapids, MI: Wm. B. Eerdmans Publishing. 


\section{A Historical analysis of Special Education}

Towns, E. L., \& Groff, R. L. (1972). Successful ministry to the retarded. Chicago: Moody Press.

Tucker, J. A. (1993). Christian education for students with disabilities: A response to Sutton, Sutton, and Everett. Journal of Research on Christian Education, 2, 289299.

United States Department of Education. (2007). My child's special needs: A guide to the individualized education program. Retrieved from http://ed.gov/parents/needs/speced/iepguide/index.html

United States Department of Education. (2009). Protecting students with disabilities:

Frequently asked questions about section 504 and the education of children with disabilities. Retrieved from http://www2.ed.gov/about/offices/list/ocr/504faq.html

Vaughn, J. C. (1993). God's mandate for special education. In J. P. Sutton (Ed.), Special education: A Biblical approach (pp. 15-44). Greenville, SC: Hidden Treasures Ministry.

Vincent, L. (2006). Special delivery: Only a handful of Christian schools provide high-end help for disabled learners. World, 21(35), 31-32.

Weber, M. C. (2007) Services for private school students under the Individuals with Disabilities Education Improvement Act: Issues of statutory entitlement, religious liberty, and procedural regularity. Journal of Law and Education, 36, 163-210.

Wilcox, C. (1992). God's warriors: The Christian right in twentieth-century America. Baltimore: John Hopkins University Press. 


\section{A Historical Analysis of Special Education}

Winzer, M. A. (2002). The history of special education: From isolation to integration. Washington, D.C.: Gallaudet University Press.

Yost, S. (n.d.). Orton-Gillingham: Who are Samuel T. Orton and Anna Gillingham? Retrieved July 2, 2010 from http://www.dyslexiaanswers.com/og.html Zettel, J. J. \& Ballard, J. (1982). The education for all handicapped children act of 1975 P.L. 94-142: Its history, origins, and concepts. In J. Ballard, B. A. Ramirez, \& F. J. Weintraub (Eds.), Special education in America: its legal and governmental foundations (pp.11-22). Reston, VA: Council for Exceptional Children.

Zorbrest V. Catalina Foothills School District, 509 U.S. 1 (1993). 